Document downloaded from:

http://hdl.handle.net/10251/50603

This paper must be cited as:

Paya-Zaforteza, I.; Garlock, ME.; Loma-Ossorio, E.; Schiffner, D.; Hospitaler Pérez, A. (2014). Analysis of a bridge failure due to fire using computational fluid dynamics and finite element models. Engineering Structures. 68:96-110. doi:10.1016/j.engstruct.2014.02.022.

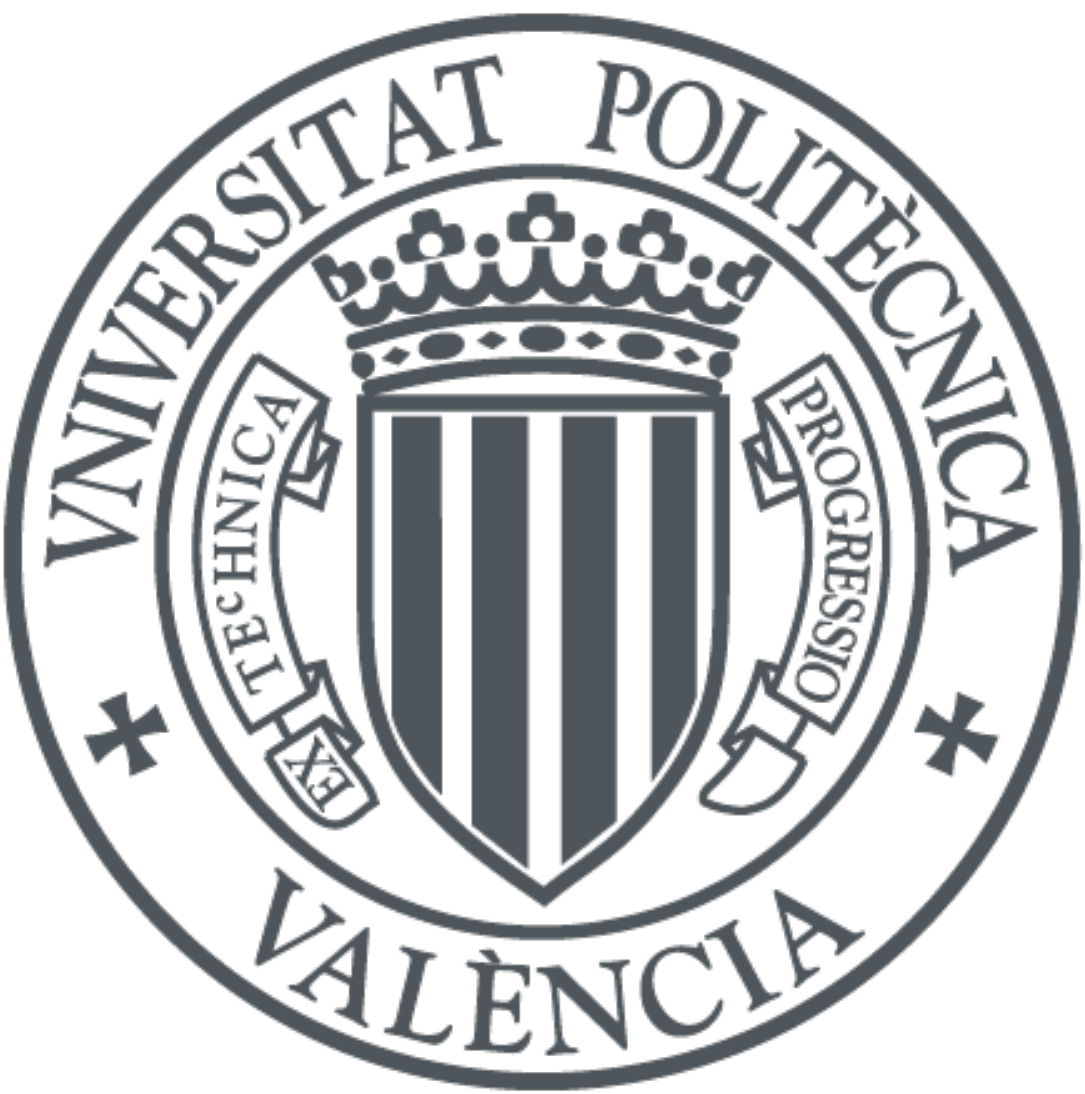

The final publication is available at

http://dx.doi.org/10.1016/j.engstruct.2014.02.022

Copyright Elsevier

Additional Information 
Please, cite this paper as:

Alos-Moya, J., Paya-Zaforteza, I., Garlock, M.E.M., Loma-Ossorio, E., Schiffner, D., Hospitaler, A. Analysis of a bridge failure due to fire using computational fluid dynamics and finite element models (2014) Engineering Structures, 68: 96-110.

DOI: 10.1016/j.engstruct.2014.02.022 
Please, cite this paper as:

Alos-Moya, J., Paya-Zaforteza, I., Garlock, M.E.M., Loma-Ossorio, E., Schiffner, D., Hospitaler, A. Analysis of a bridge failure due to fire using computational fluid dynamics and finite element models (2014) Engineering Structures, 68: 96-110.

DOI: 10.1016/j.engstruct.2014.02.022

\title{
Analysis of a bridge failure due to fire using computational fluid dynamics and finite element models
}

\author{
J. Alos-Moya ${ }^{1}$, I. Paya-Zaforteza ${ }^{1 *}$, M.E.M. Garlock ${ }^{2}$, E. Loma de Osorio ${ }^{3}$, D. Schiffner ${ }^{4}$, A. \\ Hospitaler $^{1}$
}

${ }^{I}$ ICITECH, Departamento de Ingeniería de la Construcción, Universitat Politècnica de València. Camino de Vera s/n, 46071 Valencia, Spain

${ }^{2}$ Department of Civil and Environmental Engineering, Princeton University, 59 Olden Street, Princeton, NJ, 08544, USA

${ }^{3}$ Fire Department of Valencia, Parque Central de Bomberos, Av de la Plata 20, 46013, Valencia, Spain

${ }^{4}$ Thornton Tomasetti, Market St 1750 Philadelphia, PA, 19103, USA

Authors e-mail addresses:

\author{
José Alos-Moya: $\quad$ joalmo11@upv.es \\ Ignacio Paya-Zaforteza: igpaza@ upv.es \\ Maria Garlock: $\quad$ mgarlock@ princeton.edu \\ Daniel Schiffner: _ dschiffner@thorntontomasetti.com \\ Eduardo Loma de Osorio eloma-ossorio@valencia.es \\ Antonio Hospitaler ahospitaler@ upv.es
}

\begin{abstract}
Bridge fires are a major concern because of the consequences that these kind of events have and because they are a real threat. However, bridge fire response is under researched and not covered in the codes. This paper studies the capabilities of numerical models to predict the fire response of a bridge and provides modeling guidelines useful for improving bridge design. To reach this goal, a numerical analysis of the fire of the I-65 overpass in Birmingham, Alabama, USA in 2002 is carried out. The analyses are based on computational fluid dynamics (CFD) for creating the fire model, and finite element (FE) software for obtaining the thermomechanical response of the bridge. The models are validated with parametric studies that consider heat release rate of the spilled fuel, discretization of the fire temperature in the transition from CFD to FE modeling, and boundary conditions. The validated model is used in a study to evaluate the influence of fire scenario (CFD versus standard fires), and live load. Results show that numerical models are able to simulate the response of the bridge and can be used as a basis for a performance-based approach for the design of bridges under fire. Additionally, it is found that applying the Eurocode standard and hydrocarbon fires along the full length of the bridge does not adequately represent a real bridge fire response for medium-long span bridges such as this case study. The study also shows that live loads essentially do not influence the response of the bridge.
\end{abstract}

Keywords: fire, bridge, CFD, steel girder bridge, I-65 overpass, performance-based design. 
Please, cite this paper as:

Alos-Moya, J., Paya-Zaforteza, I., Garlock, M.E.M., Loma-Ossorio, E., Schiffner, D., Hospitaler, A. Analysis of a bridge failure due to fire using computational fluid dynamics and finite element models (2014) Engineering Structures, 68: 96-110.

DOI: $10.1016 /$ j.engstruct.2014.02.022

* Corresponding author. Tel: +34 963877562; fax: +34 963877568

\section{Introduction}

Bridges are a critical component of the transportation system whose loss can result in important social and economical consequences (e.g. Chang and Nojima [1], Zhu et al. [2]). Therefore, a lot of effort has been paid to understand and predict the effects on bridges of accidental extreme load events such as earthquakes, winds, scour, and ship collisions (e.g. Ghosn et al. [3], Cheng [4]). Fire is an additional major hazard in bridges for two reasons. First, traffic on bridges damaged by fire is usually hard to detour and affects the traffic quality in the region. For example, the collapse of two spans of the MacArthur Maze in Oakland, USA on April 29th 2007 due to a fire resulted in repairs and rebuilding operations costing more than US $\$ 9$ million $[5,6]$. Another example is provided by a bridge fire caused by a dump truck in Robbinsville (NJ, USA) on October 3rd 2012. This fire forced to close the Interstate 95 Highway as well as $79 \mathrm{~km}$ of the New Jersey Turnpike, one of the major highways in the US East Coast, and affected the traffic in areas located hundreds of kilometers away of the accident in the states of Delaware and Connecticut. The accident also caused serious traffic disruptions for six weeks following the event [7]. Secondly, bridge fires are a real threat as shown by data of a voluntary bridge failure survey, which was responded by the departments of transportation of 18 US states [8]. This survey was conducted in 2011 and collected data related to 1746 bridge failures and showed that fire had caused more bridge collapses than earthquakes (seismic states like California participated in the survey).

Despite its importance, bridge fires have got very little attention in the past as proved by Garlock et al. [9]. In fact, fire safety engineering and structural fire engineering have mainly been concerned with building and tunnel fires (e.g. Buchanan [10], Couto et al. [11], Quiel et al. [12], Gunalan and Mahendran [13], López-Colina et al. [14], Moliner et al.[15] and Seif and McAllister [16]), but bridge fires are different to those and deserve a particular approach. This is due to several reasons such as the cause of fire, the fire loads, the fire ventilation conditions, the use of fire protection, and the type of connections among structural members used (see Paya-Zaforteza and Garlock [17] for more details).

Within this general context, and using a case study, this paper (a) delves into the fire response of steel girder composite bridges as this type of bridge is widely used [18] and is especially vulnerable to fire events [9], and (b) illustrates modeling techniques that can be used to predict the fire response of steel bridges. To reach this goal, the authors have 
Please, cite this paper as:

Alos-Moya, J., Paya-Zaforteza, I., Garlock, M.E.M., Loma-Ossorio, E., Schiffner, D., Hospitaler, A. Analysis of a bridge failure due to fire using computational fluid dynamics and finite element models (2014) Engineering Structures, 68: 96-110.

DOI: 10.1016/j.engstruct.2014.02.022

performed a numerical investigation of the behavior of the I-65 overpass in Birmingham (AL, USA) during the fire event on January $5^{\text {th }}$ 2002. The event resulted in the demolition of the overpass and the rebuilding of a new structure and affected highways carrying 240,000 vehicles per day. The numerical investigation is based on data provided by the Alabama Department of Transportation (ALDOT) and comprises a fire model of the event using computer fluid dynamics (CFD) techniques with the software FDS [19], and a thermomechanical model of the response of the bridge using Abaqus [20]. Numerical results were validated by comparison with the information provided by ALDOT which (a) enables a better understanding of the advantages and the limitations of numerical models to explain the fire response of bridges and (b) paves the way for the use of these models to study the improvement of the fire response of bridges in high fire risk situation. This kind of knowledge is of major importance for two reasons. First, previous research (see e.g. Payá-Zaforteza and Garlock [17], Aziz and Kodur [21]) is scarce and based more on standard fires or predefined fire events, than on the analysis of real cases and therefore has limitations. And second, it is difficult to conduct full scale experimental studies on bridges because of the dimensions of their structural members and the fire loads required.

\section{Case study.}

The I-65 overpass is a three spans bridge located in Birmingham (Alabama, USA) which enables the Interstate I-65 North highway to cross over the I-65 Interstate South highway. The original design of the bridge had a total length of $88.53 \mathrm{~m}$. distributed in a central span of $37.32 \mathrm{~m}$. and two lateral spans of 25.91 and $25.30 \mathrm{~m}$. (see Fig. 1). Each span was a simply supported deck with a composite cross section defined by a reinforced concrete slab structurally connected with shear studs to built-up I-sections made of A36 steel.

Fig. 1c shows the cross section of the central span which was the span that experienced the most damage during the fire. It had seven built up I-girders with a variable depth between $1.442 \mathrm{~m}$ (mid-span section) and $1.432 \mathrm{~m}$ (supports section). The girders supported a reinforced concrete slab $15.40 \mathrm{~m}$. wide having an average depth of $0.16 \mathrm{~m}$. Fig. 2 provides the geometric definition of Girder 1 which experienced the largest deflections during the fire event. Girder 1 had a total of 34 stiffeners. Four of them were located on the girder supports and had a thickness of $25.4 \mathrm{~mm}$ ( $1 \mathrm{inch}$ ) and the rest were located on the side of Girder 1 facing Girder 2 and had a thickness of $11 \mathrm{~mm}$. Cross braces were placed every $6.2 \mathrm{~m}$. and at the supports to provide lateral stability to the bridge deck. There were two expansion joints between the central span and the lateral spans each one having a width of $38 \mathrm{~mm}$. 
Please, cite this paper as:

Alos-Moya, J., Paya-Zaforteza, I., Garlock, M.E.M., Loma-Ossorio, E., Schiffner, D., Hospitaler, A. Analysis of a bridge failure due to fire using computational fluid dynamics and finite element models (2014) Engineering Structures, 68: 96-110.

DOI: 10.1016/j.engstruct.2014.02.022

At about 10:15 am on January 5th, 2002 a tanker truck traveling North on the 1-65 carrying $37.5 \mathrm{~m}^{3}$ of gasoline, swerved and crashed into the piers supporting the North East end of the central span. The columns survived the impact because they were protected by a $0.50 \mathrm{~m}$ height wall but when the truck and the spilled fuel caught fire under the overpass, the composite bridge suffered serious damage after some minutes (see Fig. 3). When the fire department quelled the fire, the girder of the central span named Girder 7 in Fig. 1c had small deflections (see Fig. 3b) but Girder 1 was very damaged and had deflections of almost $2.5 \mathrm{~m}$ in a section located around $15 \mathrm{~m}$. from its North end (Fig. 3a) [22]. The bridge deck could not be rehabilitated and was demolished and replaced by a new precast prestressed concrete deck. The new structure was opened to traffic 54 days after the accident. The cost resulting from closure of the overpass was estimated at 100,000 US $\$$ per day $(5,400,000$ US $\$$ in total) and the cost of the new bridge was $3,396,421$ US $\$[22,23]$. Therefore, the final cost of the accident can be estimated to be around 8.8 US \$ millions.

In the next few sections a numerical analysis of the Alabama case study is carried out in three steps. First, a model of the fire event is built with the computer fluid dynamics software FDS [19] (Section 3). Then, temperatures in the most fire-exposed girder of the overpass are obtained through a thermal analysis with the software Abaqus [20] (Section 4.1). Finally, the structural response of the most exposed girder is obtained using Abaqus [20] and considering non-linearities (geometrical and mechanical) as well as temperature dependent material properties (Section 4.2).

\section{Computer fluid dynamics (CFD) Model}

A fire model of the event was developed with the software Fire Dynamics Simulator (FDS) [19]. FDS is a software designed to predict the values of fire engineering related variables such as temperatures, heat fluxes or gas pressures in fire events. It is based on CFDs techniques and contains large eddy simulation (LES) turbulence models. The software has been developed at the National Institute of Standards and Technology (NIST) of the USA and has been extensively validated experimentally [24].

Building a FDS model requires defining: (1) a control volume with its boundary conditions which represents the volume where all the analysis will be carried out, (2) a geometry included in the control volume which is submitted to fire load, (3) a mesh or a discretization of the control volume, (4) material properties (conductivity, density, specific heat and emissivity), (5) fire sources, (6) a combustion model, and (7) sensors or elements of the model where outputs of the analysis (e.g. temperatures) are recorded. All the FDS models 
Please, cite this paper as:

Alos-Moya, J., Paya-Zaforteza, I., Garlock, M.E.M., Loma-Ossorio, E., Schiffner, D., Hospitaler, A. Analysis of a bridge failure due to fire using computational fluid dynamics and finite element models (2014) Engineering Structures, 68: 96-110.

DOI: 10.1016/j.engstruct.2014.02.022

were run as a MPI parallel job on a cluster made of HP Proliant DL 580 servers (4 six-core AMD Opteron Model 8439 SE), under a Torque resource manager and scheduler. The resources assigned were 16 cores and 8 GB RAM per core. A typical simulation took three days and four hours.

\subsection{Control volume}

The control volume must be wide enough to adequately represent the volume affected by the fire but small enough to enable the model to be run in a reasonable computing time. Fig. 4 shows the control volume used in this research as well as its boundary conditions. It contains the I-65 overpass as well as its approaches and surroundings, and has plan dimensions of $115.2 \mathrm{~m}$ per $39.6 \mathrm{~m}$ and a height of $16.2 \mathrm{~m}$. The volume has a total of $6,998,400$ parallelepiped cells, having all the cells dimensions of $0.24 \mathrm{~m}$ per $0.22 \mathrm{~m}$ per 0.20 $\mathrm{m}$. The overpass geometry was obtained from the original construction drawings of the bridge provided by ALDOT and was simplified as detailed in [25].

The size of the control volume and the size of the FDS mesh were obtained through a three step sensitivity study. First, the FDS mesh was fixed and the size of the control volume was obtained (step 1). Second, the size of the control volume was fixed and the FDS mesh was refined (step 2). Third, it was necessary to check that the control volume did not have to be modified due to changes in the FDS mesh between step 1 and step 2 (step 3). These steps are described next.

\section{- Step 1.}

The initial dimensions of the control volume were $115.2 \mathrm{~m} \times 32 \mathrm{~m} \times 12 \mathrm{~m}$ along the $\mathrm{x}, \mathrm{y}$ and z-directions respectively. A value of $115.2 \mathrm{~m}$ was chosen for the control volume length to include the full bridge as well as part of its approaches. By selecting a $32 \mathrm{~m}$ control volume width, the east border of the control volume was $3 \mathrm{~m}$ away from the east side of the bridge and the west border was $3 \mathrm{~m}$ away from the further west point of the fire footprint, what the authors considered a reasonable starting point. Finally, the maximum level ( $z$ coordinate) of the control volume was initially chosen to be four meters above the top face of the bridge concrete slab what gave the control volume an initial height of $12.0 \mathrm{~m}$. These dimensions of the control volume were increased until the temperatures in four control points did not change in two successive iterations. The resulting dimensions of the control volume were $115.2 \mathrm{~m}$ (length) $\times 38.4 \mathrm{~m}$ (width) $\times 16.0 \mathrm{~m}$ (height). In all the analyses, the control volume was meshed using cubic cells of size $0.40 \mathrm{~m}$. 
Please, cite this paper as:

Alos-Moya, J., Paya-Zaforteza, I., Garlock, M.E.M., Loma-Ossorio, E., Schiffner, D., Hospitaler, A. Analysis of a bridge failure due to fire using computational fluid dynamics and finite element models (2014) Engineering Structures, 68: 96-110.

DOI: 10.1016/j.engstruct.2014.02.022

- Step 2.

Once the control volume size was obtained, the mesh had to be refined. The authors tried three different meshes with cubic cells of size $0.40 \mathrm{~m}, 0.30 \mathrm{~m}$, and $0.20 \mathrm{~m}$. They verified that the temperatures in the control points were the same for the meshes with cells of size 0.30 $\mathrm{m}$ and $0.20 \mathrm{~m}$ and that both cell sizes could then be used. Finally cells of size $0.24 \mathrm{~m}$ (along $\mathrm{x}$-direction), $0.22 \mathrm{~m}$ (along $\mathrm{y}$-direction), and $0.20 \mathrm{~m}$ (along $\mathrm{z}$-direction) were selected to get a mesh that provided a good approximation to the geometry of the overpass. Note that the FDS mesh does not coincide with the mesh used in the software used in the thermomechanical models (Abaqus). Note also that the dimensions of the control volume had to be slightly modified so it could accommodate the new cell sizes, which resulted in the control volume dimensions shown in Fig. 4: $115.2 \mathrm{~m}$ (length) x $39.6 \mathrm{~m}$ (width) x $16.2 \mathrm{~m}$ (height).

\section{- $\quad$ Step 3.}

In step 3 it was checked that changes in the FDS mesh size from step 1 to step 2 did not affect the size of the control volume.

\subsection{Fire Load}

The fire load, located in the area of $185.13 \mathrm{~m}^{2}$ shown in Fig. 5 , is modeled using the mixture fraction combustion model proposed by FDS [27] with a soot yield of 0.018 according to [28]. This area has two components. The first one, red-filled in Fig. 5, measures $30 \mathrm{~m}^{2}$ and corresponds to the fuel burning in the tanker after the accident. The second one, brown-filled in Fig. 5, measures $155.13 \mathrm{~m}^{2}$ and corresponds to the fuel spilled on the road by the accident. The authors could not find any official report detailing the extension of the areas detailed in Fig. 5. Therefore, these areas were estimated on the basis of the analysis of the pictures of the fire event and of the damage observed in the overpass girders. Note that the footprint of the fire affects the severity of the fire by directly influencing the rate of fuel consumption, the flame height, and the total heat release of the fire. A parametric study on the influence of this footprint is not included in this paper but the interested reader can find in Peris-Sayol et al. [29] a study of this kind performed for a steel girder bridge of $12.2 \mathrm{~m}$ of span length.

The heat release rate per unit area (HRRPUA) curves increase linearly from 0 to their maximum values (HRRPUA $A_{M A X}$ ) in 20 seconds and remain constant until the failure. The HRRPUA $_{\text {MAX }}$ is $2500 \mathrm{~kW} / \mathrm{m}^{2}$ [30] in the area corresponding to the fuel burning in the tanker. A parametric study is developed in Section 5.1 to determine HRRPUA MAX $_{\text {for }}$ the area 
Please, cite this paper as:

Alos-Moya, J., Paya-Zaforteza, I., Garlock, M.E.M., Loma-Ossorio, E., Schiffner, D., Hospitaler, A. Analysis of a bridge failure due to fire using computational fluid dynamics and finite element models (2014) Engineering Structures, 68: 96-110.

DOI: 10.1016/j.engstruct.2014.02.022

corresponding to the spilled fuel. A minimum value of $500 \mathrm{~kW} / \mathrm{m}^{2}$ is considered in the parametric study because according to [31] the HRRPUA ${ }_{M A X}$ of the spill fire can be estimated to be one-fifth of the HRRPUA $A_{\text {MAX }}$ of the fuel burning in the tanker. However, fuel accumulations due to the slope of the $1-65 \mathrm{~N}$ and the presence of a concrete barrier (see Fig. $3 d)$ could result in values of the HRRPUA $A_{\text {MAX }}$ in the spilled fuel area higher than $500 \mathrm{~kW} / \mathrm{m}^{2}$. The maximum possible value of the HRRPUA $\mathrm{MAX}_{\text {for }}$ the spill fire is $2500 \mathrm{~kW} / \mathrm{m}^{2}$ because it cannot be higher than the HRRPUA $A_{\text {MAX }}$ of the fuel burning in the tanker. To complete the parametric study, three intermediate values between 500 and $2500 \mathrm{~kW} / \mathrm{m}^{2}$ are considered: 1000,1500 and $2000 \mathrm{~kW} / \mathrm{m}^{2}$. Note also that the HRRPUA curves do not have any decay phase because the numerical model results show that the overpass failed when only $15 \%$ of the available fire load was consumed.

\subsection{Adiabatic temperatures}

The adiabatic surface temperature developed by Wickström et al. [26] is used to transfer the information obtained by the fire model to the thermal model. This adiabatic surface temperature is a fictitious temperature obtained by FDS assuming that the structural element is a perfect insulator and is commonly used for calculating both convective and radiative heat transfer. It is an effective temperature depending on the incident heat flux by radiation and convection to a surface and the gas temperature adjacent to that surface. This temperature can then be considered as an equivalent fire temperature when calculating the heat flux to an exposed structure and enables an easy introduction of the fire model results in the thermo-mechanical model.

The model includes 5754 sensors to measure the adiabatic temperatures in 417 crosssections of the overpass. Cross sections located on the supports were monitored with 12 sensors whereas the rest of sections were monitored with 14 sensors (see Fig. 6).

Fig. 7a shows the fire scenario 3 minutes after the beginning of the fire event. Fig. $7 \mathrm{~b}$ shows the evolution of the adiabatic surface temperatures $\left(T_{a}\right)$ in the cross section of Girder 1 located at $7.5 \mathrm{~m}$ from its North end. Note that for clarity, Fig. $7 \mathrm{~b}$ does not contain results measured by all the sensors. It is seen that sensors 2 through 7 , representing the west (open to air) face of Girder 1 have essentially the same temperature. Although not shown, sensors 2' through 7', representing the east face (adjacent to Girder 2), also measure essentially the same temperature. These temperatures are similar to those measured by sensors 4 and 4' respectively (differences are lower than 5\%). Similarly, the temperatures measured by sensors 1 and 1' are almost the same. 
Please, cite this paper as:

Alos-Moya, J., Paya-Zaforteza, I., Garlock, M.E.M., Loma-Ossorio, E., Schiffner, D., Hospitaler, A. Analysis of a bridge failure due to fire using computational fluid dynamics and finite element models (2014) Engineering Structures, 68: 96-110.

DOI: $10.1016 /$ j.engstruct.2014.02.022

Therefore, to simplify the transition from the CFD to finite element model, each girder cross section was divided in three parts, each having a shared adiabatic temperature: The West Face, Bottom Face and East Face have adiabatic temperatures measured by sensors 4,1 , and 4' respectively.

Fig. $8 \mathrm{a}$ and $8 \mathrm{~b}$ plot average adiabatic surface temperature values at the girder mid-depth (sensors labeled as 4 and 4' in Fig. 6) in the steady state (between 50 and 400 seconds after the beginning of the fire). This temperature is plotted along each girder's longitudinal axis, $x$, where $x=0$ represents the north end. Fig. $8 \mathrm{a}$ and $8 \mathrm{~b}$ show that particularly in girders 1 and 2 there is a large variation of the adiabatic temperatures along the longitudinal axis. For example, adiabatic temperatures vary between $841^{\circ} \mathrm{C}$ and $185^{\circ} \mathrm{C}$ in the West Face and between $867^{\circ} \mathrm{C}$ and $495^{\circ} \mathrm{C}$ in the East face of Girder 1 ; between $381^{\circ} \mathrm{C}$ and $238^{\circ} \mathrm{C}$ in the West Face Girder 7, and between $166^{\circ} \mathrm{C}$ and $73^{\circ} \mathrm{C}$ in the East Face Girder 7. Also, results show peak temperatures in the regions of girders 1 and 2 directly affected by the fire flames.

Fig. $8 \mathrm{c}$ plots the temperature difference between the West and East faces of the girders (sensor 4 minus sensor 4'). A negative value therefore implies that the East Face is hotter than the West Face. It is seen that for the exterior girders (Girders 1 and 7) temperatures in the East and West faces can be very different. The maximum temperature difference ranges from $-311^{\circ} \mathrm{C}$ in Girder 1 to $+284^{\circ} \mathrm{C}$ in Girder 7 . These values represent $36 \%$ and $19 \%$ of the maximum adiabatic temperatures of each girder. The fire occurred on the west side of the span, near Girder 1. Therefore, temperatures in the West face of the girders are generally higher than in the East face with the exception of Girder 1, whose West face does not have any important obstacle to avoid the free rising of hot gases.

It is noted that although the analyses presented in Figure 7 and 8 were done assuming

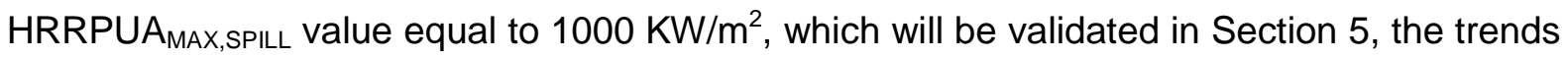
and discussion do not change with other values of HRRPUA $A_{M A X, S P I L L}$.

\section{Finite element (FE) model for thermo-mechanical analysis}

In this section, the girder which suffered more damage during the fire event, i.e. Girder 1, and its corresponding concrete slab are analyzed using an uncoupled thermomechanical analysis. The width of the slab in the FE model is $2.2 \mathrm{~m}$ according to the dimensions plotted in Fig. 1c. In the first step (the thermal analysis) the structure is heated using the adiabatic surface temperatures given by FDS, and the heat transfer method provides the transient nodal temperatures with respect to time. In the second step (the structural analysis), the nodal temperatures are read from the thermal analysis and 
Please, cite this paper as:

Alos-Moya, J., Paya-Zaforteza, I., Garlock, M.E.M., Loma-Ossorio, E., Schiffner, D., Hospitaler, A. Analysis of a bridge failure due to fire using computational fluid dynamics and finite element models (2014) Engineering Structures, 68: 96-110.

DOI: 10.1016/j.engstruct.2014.02.022

corresponding temperature dependent mechanical material properties are used to find the equilibrium of the structure. All the analyses are carried out using the FE software Abaqus [20]. All the Abaqus models were run in a computer with an i7-3770 processor of 3.4-3.9 $\mathrm{GHz}$ and $32 \mathrm{~GB}$ of RAM, typically resulting in a simulation run time of three hours.

To validate both the CFD and FE models, parametric studies are performed in Section 5 where the results are compared to the case study fire event. The following CFD and FE model characteristics are used as part of that parametric study: (1) the fire load as affected by HRRPUA $A_{\text {MAX }}$ of the fuel spill (as described in Section 3.2); (2) the discretization of temperature along the length of the girder; and (3) the boundary conditions through constraints on the roller support motion. This section introduces these parameters, and Section 5 discusses the results.

\subsection{Elements and mesh}

For the thermal analysis, Abaqus element DC3D8 is employed. This is a three dimensional eight-noded linear heat transfer brick element with one degree of freedom per node. For the structural analysis, Abaqus element C3D8 is used, which is a three dimensional eight-noded solid continuum element with three degrees of freedom per node. FE analyses include geometric and material non-linearity. A complex FE model with solid elements is used instead of a simpler model with beam elements to capture local phenomena such as web buckling that might control the global response and the failure mode of the bridge. Fig. 9 shows a 3D view of the model. Note that the mesh is finer in the vicinity of the supports because these are areas of high stress more susceptible to local buckling. The FE model has 87791 nodes and 61620 solid elements.

\subsection{Material properties.}

Thermal properties suggested by EC-4 [32] were used for concrete and steel elements respectively. It was assumed that concrete aggregates were calcareous and that concrete unit mass, $\rho_{c}$, was $2500 \mathrm{~kg} / \mathrm{m}^{3}$. According to the drawings of the overpass project, a value of the concrete compressive strength of $27.58 \mathrm{MPa}$ (4000 psi) at ambient temperature was assumed and used to build concrete stress-strain curves according to EC-4 [32]. A value for the unit mass of steel, $\rho_{s}$, of $7850 \mathrm{~kg} / \mathrm{m}^{3}$ was used along with the stressstrain curves with strain hardening proposed by EC-4 [32] for steel with a yield stress at ambient temperature, $f_{y}$, of $248.21 \mathrm{MPa}$ (36 ksi). Finally, engineering values of stresses $(\sigma)$ and strains $(\varepsilon)$ were converted into true stress strain laws $\left(\sigma_{n}-\varepsilon_{n}\right)$ and introduced in Abaqus as detailed in Eq. 1 and 2. 
Please, cite this paper as:

Alos-Moya, J., Paya-Zaforteza, I., Garlock, M.E.M., Loma-Ossorio, E., Schiffner, D., Hospitaler, A. Analysis of a bridge failure due to fire using computational fluid dynamics and finite element models (2014) Engineering Structures, 68: 96-110.

DOI: 10.1016/j.engstruct.2014.02.022

$$
\begin{array}{ll}
\sigma_{n}=\sigma(1+\varepsilon) & \text { (Eq. 1) } \\
\varepsilon_{\mathrm{n}}=\ln (1+\varepsilon) & \text { (Eq. 2) }
\end{array}
$$

\subsection{Discretization of temperature along girder length}

Adiabatic surface temperatures obtained with FDS are considered as uniform temperatures in the gas surrounding the structure and, therefore, are used to heat the deck. In the thermal analysis a convective heat transfer coefficient, $h_{c}$, of $50 \mathrm{~W} / \mathrm{m}^{2} \mathrm{~K}$ and an emissivity coefficient, $\varepsilon$, of 0.7 corresponding to a petrol fire was used according to EC-1 [31] and EC-4 [30].

Curves giving FDS adiabatic surface temperatures such as those of Fig. $8 \mathrm{a}$ and $8 \mathrm{~b}$ have been discretized (modeled as stepped curves) to facilitate merging with Abaqus. The coarseness or fineness of the discretization is a parameter to be studied in Section 5.2. The study divided the length of the girder into 1, 2, 4, 8, and 16 equal segments. Using a value of one implies uniform temperature along the full length of the girder. Fig. 10 shows an example using a 16 step discretization and compares, for this case, the adiabatic temperature curves obtained with FDS to the stepped curves introduced in Abaqus (assuming HRRPUA $A_{\text {MAX,SPILL }}=1000 \mathrm{KW} / \mathrm{m}^{2}$ ). As explained in Section 3.3, temperatures measured by sensors 4, 4' and 1 have been taken as representative of the temperatures in the West, East and Bottom faces of Girder 1 respectively.

\subsection{Boundary conditions.}

The bridge studied in this paper was a composite bridge, i.e., the steel girders and the concrete slab where connected with shear connectors to ensure that both elements worked together to sustain the loads acting on the bridge. However, temperatures caused by the fire can deteriorate the connectors and reduce the load bearing capacity of the deck.

All the analyses carried out in the present work consider full composite action through the full fire event. This assumption is based on two facts: (a) there was no evidence showing a steel-concrete connection failure due to the fire event, and (b) numerical models showed that temperatures in the interface between the steel girder and the slab during the fire event were smaller than $500^{\circ} \mathrm{C}$ (see Section 6.1). Other boundary conditions considered are:

- Lateral "y" displacements (named u3 in Fig. 9) at the supports ( $x=0.53 \mathrm{~m}$ and $x=35.66$ m) are fixed at the level of the concrete slab to take into account the influence of parts of slab not included in the FE model. Note that fixing these lateral displacements along 
Please, cite this paper as:

Alos-Moya, J., Paya-Zaforteza, I., Garlock, M.E.M., Loma-Ossorio, E., Schiffner, D., Hospitaler, A. Analysis of a bridge failure due to fire using computational fluid dynamics and finite element models (2014) Engineering Structures, 68: 96-110.

DOI: 10.1016/j.engstruct.2014.02.022

the full length of Girder 1 would result in null lateral displacements of the top part of the composite girder which is not possible due to the transverse rotations and large deflections experienced by Girder 1 during the fire event

- The south support of the girder was considered as pinned and the north support was considered to be a roller. The extent of roller motion is a parameter in the study. As explained by Paya-Zaforteza and Garlock [17], it is important to consider when studying the fire response of a bridge that temperature variations in the deck caused by a fire are significantly larger than those due to weather changes. These temperatures can provoke deck expansion movements which might be eventually restrained by the abutments or an adjacent span. To consider this possibility, two types of numerical analyses were carried out. The first one corresponds to a situation where the bridge is allowed to freely expand without any restraint. The second one corresponds to a more realistic situation where the bridge is allowed to expand only up to the width of the expansion joint. Therefore, and only for the latter case, a rigid body was created at a distance from the North outer cross section of the bridge equal to the expansion joint width $(0.152 \mathrm{~m}$.). In doing so, the axial expansion of the nodes of the outer cross section of the bridge was restrained once their horizontal displacement equaled the width of the expansion joint. Section 5.3 discusses the effects of including or excluding this axial expansion restraint.

\subsection{Gravity Loads}

Gravity loads corresponding to the self weight of the of steel girder (130.6 kN in total) and the concrete slab (327.98 kN in total) are computed automatically by the software. Furthermore, a total dead load of $121.2 \mathrm{kN}$ corresponding to the weight of the wearing surface of the deck and of $83.6 \mathrm{kN}$ along the $0.2 \mathrm{~m}$ west end of the girder corresponding to the safety barrier weight have been also considered.

The authors did not find any evidence of vehicles (live load) crossing the I-65 overpass while it was on fire so only the above mentioned dead loads are considered in the model validation of the case study. However, an analysis of the effects of live load is done in Section 6.3

\section{Parametric Study for Model Validation.}

As mentioned previously, parametric studies are performed to validate the CFD and FE models. The results are compared to the case study fire event. The following model parameters are studied: (1) the fire load as affected by HRRPUA $A_{\text {MAX }}$ of the fuel spill; (2) the 
Please, cite this paper as:

Alos-Moya, J., Paya-Zaforteza, I., Garlock, M.E.M., Loma-Ossorio, E., Schiffner, D., Hospitaler, A. Analysis of a bridge failure due to fire using computational fluid dynamics and finite element models (2014) Engineering Structures, 68: 96-110.

DOI: $10.1016 /$ j.engstruct.2014.02.022

discretization of temperature along the length of the girder; and (3) the boundary conditions through restrained thermal expansion.

Table 1 presents the model parameters studied (as introduced in Section 4) and the analysis names where the nomenclature is as follows: the first number represents the HRRPUA $A_{\text {MAX, }}$ the second number represents the discretization of temperature along the length, and 'fre' or 'fix' represents a boundary condition with unlimited free thermal expansion or a limited thermal expansion, respectively.

The times to failure and the structural response at this time are discussed in each of the subsections to follow. In the structural analysis, the transient nodal temperatures with respect to time obtained with the thermal analysis are used to find the equilibrium of the structure considering temperature dependent mechanical material properties, second order effects, and gravity loads. As proposed by Payá-Zaforteza and Garlock [17], the structure is assumed to fail when any of the following conditions is fulfilled:

(1) Fracture occurs, which is assumed to happen when the ultimate strain $\varepsilon_{u}$ of the material is attained. This mode of failure is checked by comparing the maximum principal strain of the structure with $\varepsilon_{u}$ based on true values (Eq. 2).

(2) The structure becomes unstable based on a drastic increase in the rate of vertical deflections or an inward movement of the roller support towards the center of the span.

\subsection{Fire Load (HRRPUA)}

As shown in Table 1, five values of maximum heat release rate per unit area in the

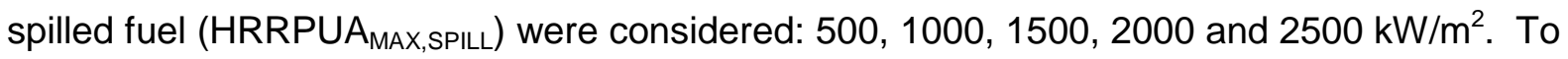
validate the value, a comparison with the structural response of the case study is done. Table 1 shows the assumptions made regarding the FE model in these analyses: discretizing the temperature along the length of Girder 1 into 16 steps (validated in Section 5.2), and a limited axial expansion ('fixed' support conditions as will be validated in Section $5.3)$.

Fig. 11 examines the effects of HRRPUA $A_{M A X, S P I L L}$ on the steady state adiabatic temperatures

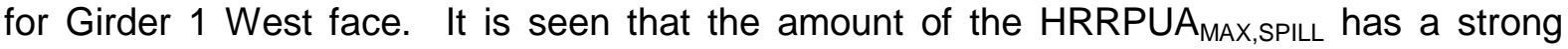
influence on the adiabatic surface temperatures along Girder 1. For example, moving from a value of $500 \mathrm{~kW} / \mathrm{m}^{2}$ to a value of $2500 \mathrm{~kW} / \mathrm{m}^{2}$ multiplies the maximum adiabatic temperatures by 1.73 (from 724 to $1251^{\circ} \mathrm{C}$ ). Although not shown, in the East face and 
Please, cite this paper as:

Alos-Moya, J., Paya-Zaforteza, I., Garlock, M.E.M., Loma-Ossorio, E., Schiffner, D., Hospitaler, A. Analysis of a bridge failure due to fire using computational fluid dynamics and finite element models (2014) Engineering Structures, 68: 96-110.

DOI: 10.1016/j.engstruct.2014.02.022

Bottom face the multiplicative difference is 2.67 (from 549 to $1469^{\circ} \mathrm{C}$ ) and 1.54 (from 811 to $\left.1251^{\circ} \mathrm{C}\right)$, respectively.

These differences in adiabatic temperature have an effect on the structural response of Girder 1. For example, Table 1 shows that increasing HRRPUA $A_{M A X, S P I L L}$ results in reducing

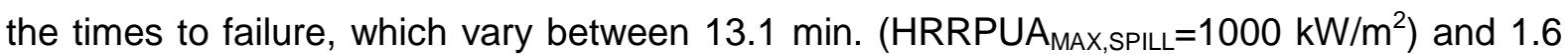
$\min \left(\right.$ HRRPUA $\left.A_{M A X, S P I L L}=2500 \mathrm{~kW} / \mathrm{m}^{2}\right)$.

Figure 12 examines the effect of HRRPUA $A_{\text {MAX, SPILL }}$ on the vertical displacement of the girder. Figure 12a plots, as a function of time, the maximum vertical displacement. It is observed that HRRPUA $A_{M A X, S P I L L}$ equal to $1000 \mathrm{~kW} / \mathrm{m}^{2}$ reaches a final maximum deflection equal to 1.91 $\mathrm{m}$ (also seen in Table 1), which is the closest to the case study value of $2.5 \mathrm{~m}$. reported by ALDOT.

Assuming a HRRPUA $A_{\text {MAX,SPILL }}$ equal to $1000 \mathrm{~kW} / \mathrm{m}^{2}$ (i.e., analysis $1000-16$-fix), Figure $12 \mathrm{~b}$ plots the displacement along the length of the girder for some discrete points in time. The arrows indicate the point of maximum deflection. It is seen that the maximum vertical deflection of the girder displaces with time towards the North end of Girder 1. This happens because the fire load is non-symmetric, which results in a non-symmetric structural response. Additionally, the point of maximum deflection given by the case 1000-16-fix is located $11.6 \mathrm{~m}$ away from the north support, only $3.4 \mathrm{~m}$ ( $9 \%$ of the span length) away from the point of maximum deflection estimated using ALDOT pictures (Fig. 3) which is located 15 m away from the north support.

Figure 13 plots (a) the horizontal displacement of the roller, and (b) the out-of-plane displacement of the web. For the analyses that did not fail too soon (HRRPUA $A_{M A X, S P I L L}$ equal to 500 and $1000 \mathrm{~kW} / \mathrm{m}^{2}$ ), it is seen that the horizontal displacement of the roller becomes a constant value once the displacement reaches the expansion joint width $(0.152 \mathrm{~m})$. This response indicates that these two analyses had the girder bear against the rigid body (see Fig. 9) and axially restrained expansion once the horizontal expansion reached $0.152 \mathrm{~m}$.

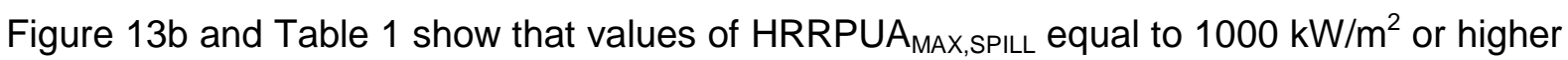
produce web buckling noticed by high transverse web displacements. Buckling is accompanied by an inward movement of the roller support towards the center of the span

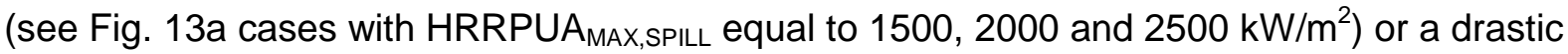
increase in the rate of vertical deflections (see case with HRRPUA $A_{M A X, S P I L L}$ equal to 1000 $\mathrm{kW} / \mathrm{m}^{2}$ in Fig. 12a).

\subsection{Discretization of the temperature along the length}


Please, cite this paper as:

Alos-Moya, J., Paya-Zaforteza, I., Garlock, M.E.M., Loma-Ossorio, E., Schiffner, D., Hospitaler, A. Analysis of a bridge failure due to fire using computational fluid dynamics and finite element models (2014) Engineering Structures, 68: 96-110.

DOI: 10.1016/j.engstruct.2014.02.022

As explained in Section 4.3 each FDS adiabatic surface temperature curve must be discretized into a stepped curve for merging CFD results into Abaqus. The higher the number of steps, the higher the precision of the analysis but also a higher computational effort. In this section, the influence of the discretization (number of steps) in the results is analyzed. The study is done for five number of steps $(1,2,4,8$ and 16) using a value of

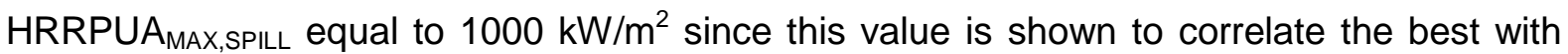
the events of the case study as discussed in the previous section. All the analyses assume a limited axial expansion ('fixed' support conditions as will be validated in Section 5.3).

Table 1 and Fig. 14 show the main results of these analyses, where Fig. 14 plots the (a) maximum vertical displacement and (b) transverse (out-of-plane) displacements of the web as a function of time for the number of discretized steps studied. Fig 14a shows that the maximum vertical displacement is affected by the discretization where the larger the number of discretized steps the larger the displacement. Fig. 14b shows that the out-of-plane displacement is also affected by the discretization. This displacement converges to a solution at a 16 step discretization since those results are close to the 8 step discretization results. In addition, the modes of failure are the same for 8 step and 16 step discretization.

Using less than 8 steps leads to results that are not consistent with the case study response. For example, maximum deflections are largely underestimated as shown in Table $1(2.5 \mathrm{~m}$ maximum deflection was reported by ALDOT). Further, models with 1 and 2 step discretizations do not produce transverse web displacements produced by web buckling as seen in the case study (see Fig. 3c).

\subsection{Axial restraint boundary conditions}

Two types of boundary conditions were considered at the roller support end. The first one allows the bridge to freely expand without any restraint (called 'fre' in Table 1). The second one corresponds to a more realistic situation where deck is allowed to expand only up to the width of the expansion joint (called 'fix' in Table 1). Therefore, and only for the 'fix' case, a rigid body was created at a distance from the North outer cross section of the bridge equal to the expansion joint width (0.152 m.) (see Fig. 9).

The analyses presented to this point have assumed a 'fix' condition, which the authors believe more closely represents the case study condition. To validate this assumption, another analysis was done, similar to analysis 1000-16-fix, but where the roller is permitted to freely move without restriction (analysis 1000-16-fre). 
Please, cite this paper as:

Alos-Moya, J., Paya-Zaforteza, I., Garlock, M.E.M., Loma-Ossorio, E., Schiffner, D., Hospitaler, A. Analysis of a bridge failure due to fire using computational fluid dynamics and finite element models (2014) Engineering Structures, 68: 96-110.

DOI: 10.1016/j.engstruct.2014.02.022

Table 1 and Figure 15 present the results of this study. Fig. 15a plots the maximum vertical displacement (VD) and the horizontal displacement (HD) of the roller as a function of time for analyses 1000-16-fix and 1000-16-fre. Fig. 15b plots the transverse (out-of-plane) displacements of the web for the same two analyses. Figure 15 shows that the trend in vertical displacement is the same for both boundary conditions, but Table 1 shows that the 'fre' analysis fails sooner than the 'fix' analysis and therefore results in smaller maximum vertical deflection. Fig. 15a also shows that the 'fix' analysis reaches the maximum horizontal displacement value of $0.152 \mathrm{~m}$ representing the extent of the expansion joint, while the 'fre' analysis continues to have its roller support move horizontally. Finally, Fig 15b shows that analysis 1000-16-fre has essentially no out-of-plane displacement oscillations of the web, indicating no web shear buckling. This is contrary to the case study response as seen in Fig. 3.

\subsection{Conclusions of Parametric Study for Model Validation}

From the three parameters studied and presented in Sections 5.1 through 5.3, the following parameters are recommended to obtain a model that represents as closely as possible the case study results:

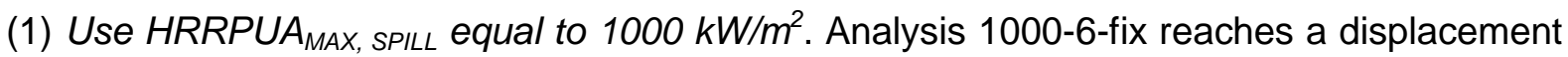
closest to that observed in the case study. The final maximum deflection in this case is 1.91 $\mathrm{m}$, which is the closest to the value of $2.5 \mathrm{~m}$. reported by ALDOT. Note that ALDOT's values were an estimation and not the result of a measurement with surveying instruments. Note also that FDS solves the CFD problem without considering the deformation of the structure. In the real event, the deformation of the structure caused by the fire brings the structure in closer proximity to the fire load resulting in higher temperatures and higher deflections.

(2) Use a 16 step discretization to model the temperature of the girder along its length. While an 8 step discretization may be acceptable, 16 steps results in maximum vertical displacements that are slightly larger and closer to the case study event. If 16 steps are used, each step has a length of $2.33 \mathrm{~m}$. Using 4 steps (step length equal to $9.29 \mathrm{~m}$ ) provides some valuable insight in the expected mode of failure but can lead to important errors in the estimation of times to failure and deflections. Using smaller number of steps for a bridge with a span length close to $37 \mathrm{~m}$ is inadvisable because of the low quality of the results obtained.

(3) Use 'fix' boundary conditions that consider the width of the expansion joint and restrain axial displacement once the movement exceeds the width. Analysis model 1000-16-fre deflections are much smaller than those of 1000-16-fix (1.36 m versus $1.96 \mathrm{~m}$ ), and this 
Please, cite this paper as:

Alos-Moya, J., Paya-Zaforteza, I., Garlock, M.E.M., Loma-Ossorio, E., Schiffner, D., Hospitaler, A. Analysis of a bridge failure due to fire using computational fluid dynamics and finite element models (2014) Engineering Structures, 68: 96-110.

DOI: 10.1016/j.engstruct.2014.02.022

model does not predict the web buckling as seen in the case study. Additionally, 'fre' boundary conditions seem less realistic as they do not include the influence of the adjacent span.

From this study it can be concluded that the model that better fits the observed response of the bridge is analysis case 1000-16-fix. Fig. 16 compares deformed shapes and failure modes obtained with validated analysis model 1000-16-fix to those observed in the real bridge. Excellent correlation is observed in the deformed shape both at the global level as represented by Fig. 16a and at the local level as represented by Fig 16b. The former shows overall vertical deflection and the latter shows web buckling in Girder 1 which also was the failure mode observed in the model 1000-16-fix. However, it must be noticed that the structural model used did not consider all the bridge girders and therefore it does not take into account load redistributions from Girder 1 to other bridge girders during the fire event.

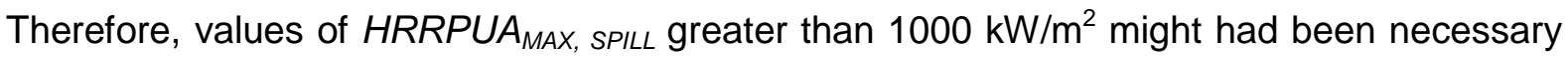
to obtain the observed deflections in the bridge.

\section{Additional Thermal and Structural Studies}

Using validated model 1000-16-fix, the following additional parameters that are not related to the model validation are examined: (1) a comparison of fire scenarios as represented by time-temperature curves obtained by CFD versus some standard curves and (2) the presence of live load. In addition, an examination of the thermal response of the case study Girder 1 is examined.

\subsection{Thermal Response of Case Study}

Fig. 17a shows the evolution along time of the temperature profiles of the cross section with " $\mathrm{x}$ " coordinate equal to $7.5 \mathrm{~m}$ (section where temperatures were maximal). A non linear thermal gradient is seen which causes mechanical strains (and therefore stresses) even if the structure is statically determinate and no gravity load is applied. Fig. 17b plots the evolution of temperatures at representative points of the same cross section. Temperatures in the steel-concrete interface are never higher than $500^{\circ} \mathrm{C}$ which justifies considering the bridge as composite as discussed in Section 4.4.

Fig. 18 displays the temperatures along the length of Girder 1 at the time of failure. There is a large variation of the temperatures along the bridge length. This variation is important to model as observed by the temperature discretization study of Section 5.2. Assuming a constant fire load along the bridge for mid-span or long-span bridges is therefore unrealistic. However, these temperatures do not experience big changes in the region directly affected 
Please, cite this paper as:

Alos-Moya, J., Paya-Zaforteza, I., Garlock, M.E.M., Loma-Ossorio, E., Schiffner, D., Hospitaler, A. Analysis of a bridge failure due to fire using computational fluid dynamics and finite element models (2014) Engineering Structures, 68: 96-110.

DOI: 10.1016/j.engstruct.2014.02.022

by flames (region with " $x$ " coordinates between $4.65 \mathrm{~m}$ and $11.61 \mathrm{~m}$ ). This suggests that assuming a uniform fire load in short span bridges can be reasonable.

The temperature in the cross section also varies. In Figs. 17 and 18 it can be seen that temperatures range from 362 to $823^{\circ} \mathrm{C}$ in the mid-web, from 237 to $702^{\circ} \mathrm{C}$ in the bottom flange and from 166 to $530 \stackrel{\circ}{\mathrm{C}}$ in the top flange.

The peaks and valleys in the curves of Fig. 18 are due to conductive heat transfer phenomena between the stiffeners and the bottom and top flanges of the girder. This phenomenon appears when the thickness of the stiffeners is different from the thickness of the web. The element with smaller thickness is heated up more quickly and transfers part of its heat to the elements at lower temperatures which are in contact with it.

\subsection{Influence of Fire Scenario}

It is a common approach in fire engineering to test building elements with the standard fire curve proposed by the Part 1-2 of the Eurocode 1 [33]. On the other hand, Paya-Zaforteza and Garlock [17] have proposed the application of the hydrocarbon fire curve of Eurocode 1 [31] to short span bridges (up to $12.20 \mathrm{~m}$ ). This section compares the response of the case study girder when subjected to the following three fire scenarios: (1) the "CFD" modeled fire presented in this paper simulating the real fire event, (2) the "standard" fire curve for building elements by the Eurocode 1; and (3) the "hydrocarbon" fire curve by the Eurocode 1. The FE model is based on validated model 1000-16-fix as discussed in Section 5.4. The results of this study are presented in Table 2 and Fig. 19 and are discussed next.

Fig. 19a plots the temperature in the middle of the web of Girder 1 in the moment of failure for the fire scenarios analyzed. It is seen that along the length of the girder, the thermal response is very different: whereas the Eurocode fire curves heated the web uniformly along the length until temperatures of $716^{\circ} \mathrm{C}$ (standard) and $762^{\circ} \mathrm{C}$ (hydrocarbon) were reached, the CFD simulated fire resulted in very variable temperatures along Girder 1, with peak values of $824 \stackrel{\circ}{\circ}$ and valley values of $313^{\circ} \mathrm{C}$. Similar results are obtained when top and bottom flanges temperatures are analyzed.

As a result of the variation in temperatures, the structural response of the girder is also very different depending on the fire scenario. Fig. 19b shows the vertical deflections of the girder at the time of failure. The final shape of the girder when heated with the Eurocode fires (building and hydrocarbon) is similar and the maximum deflections are around $1.15 \mathrm{~m}$ in both cases, thus $40 \%$ smaller than the maximum deflections obtained when the bridge is heated with the CFD simulation. 
Please, cite this paper as:

Alos-Moya, J., Paya-Zaforteza, I., Garlock, M.E.M., Loma-Ossorio, E., Schiffner, D., Hospitaler, A. Analysis of a bridge failure due to fire using computational fluid dynamics and finite element models (2014) Engineering Structures, 68: 96-110.

DOI: $10.1016 /$ j.engstruct.2014.02.022

Table 2 shows that the times to failure are very different: 17.4 min for the Eurocode building fire, $5.3 \mathrm{~min}$ for the Eurocode hydrocarbon fire and $13.1 \mathrm{~min}$ for the CFD simulation. Therefore, the Eurocode building fire curve overestimates the time to failure by $33 \%$ and the Eurocode hydrocarbon fire curve underestimates the time to failure by $59 \%$ compared to the CFD fire simulation. The smaller times to failure of the hydrocarbon curve can be explained by the fact that temperatures in the girder when the hydrocarbon fire is used are generally much higher than when the CFD model is used which results in (a) more loss of stiffness and resistance as the mechanical properties of the materials are temperature dependent and (b) more internal forces caused by the contact of Girder 1 with the adjacent span as the free thermal expansion of Girder 1 is bigger. The longer times to failure of the Eurocode building fire are due to the fact that its temperatures increase with a lower rate than the hydrocarbon or the CFD fires

All the analyses predict the failure of the girder by web buckling but the location of the failure is different: north end in the CFD simulation and south end in the both Eurocode fires. Note that temperatures in the south end of the girder are much higher in models using Eurocode fire curves than in the model using the CFD simulation, which explains the change in the location of the failure.

From this study, it seems that any fire whose footprint is less than the length of the bridge may not be conducive to the use of the standard or hydrocarbon fire curves over the entire length of the bridge deck. It may be more appropriate in those cases to apply the standard or hydrocarbon fire over a partial length of the bridge at the fire location and taper the fire temperatures according to the distance from the fire. Additional research is required to define how to scale standard curves up and down along the longitudinal axis of the bridge to make them represent real bridge fire scenarios.

\subsection{Influence of Live Load}

Finally, the influence of the live loads in the fire response of the bridge is analyzed. This study is motivated by the absence in the fire codes such as the Eurocode 1 Part 1-2 [33] or in the bridge standards such as the Eurocode 1 Part 2 [34] of any recommendation related to the live load to be considered when studying the fire response of a bridge. Previous work carried out by Paya-Zaforteza and Garlock [17] has found that live loads have very little influence, but this conclusion was obtained for a short span bridge with a span length of 12.2 m. No studies have been done for medium-long span bridges as our case study. 
Please, cite this paper as:

Alos-Moya, J., Paya-Zaforteza, I., Garlock, M.E.M., Loma-Ossorio, E., Schiffner, D., Hospitaler, A. Analysis of a bridge failure due to fire using computational fluid dynamics and finite element models (2014) Engineering Structures, 68: 96-110.

DOI: $10.1016 /$ j.engstruct.2014.02.022

Table 3 presents the four live load cases studied. The first one is the baseline case, which has no live load (only dead load) and represents the validated model 1000-16-fix described in Section 5. The next three cases modify the baseline case by adding three different values of live load: $1.2 \mathrm{kN} / \mathrm{m}, 2 \mathrm{kN} / \mathrm{m}$ and $4 \mathrm{kN} / \mathrm{m}$ representing $30 \%, 50 \%$ and $100 \%$ of the live load acting on Girder 1 according to the AASHTO LRFD Bridge Design Specifications [35]. This live load does not include any truck as the authors have not found any evidence of a truck crossing a bridge while it was on fire.

Table 3 and Fig. 20 summarize the main results, where Fig. 20 plots the evolution of maximum deflections over time. One notices that if live load is added, the times to failure decrease up to $13.7 \%$ when the full live load is acting. Maximum deflections do not appreciably change and the modes of failure and failure location remain the same: in every case, the girder experiences web buckling in the section located at $4.5 \mathrm{~m}$ of its north end accompanied by lateral buckling. The small influence of the live load can be explained by the fact that the dead load acting on Girder 1 is $17.8 \mathrm{kN} / \mathrm{m}, 4.4$ times more than the maximum live load acting on the same girder.

These results indicate that the amount of live load does not seem to have any representative influence from the engineering point of view in the fire response of steel girder bridges with span lengths up to $37 \mathrm{~m}$.

\section{Conclusions and future work.}

Bridge fires are currently a major concern due to the number of fire events and corresponding social and economic consequences. However, there are very few studies on this topic and, in addition, experimental studies are difficult to conduct due to the large dimensions that bridge elements typically have and the fire loads required. Therefore, it is of major importance to develop numerical models to characterize bridges fire response. The validity of these models must be checked with data coming from real fire events.

In this paper, the authors have first developed numerical models to analyze the behavior of the I-65 overpass in Birmingham, Alabama, USA during the fire event that happened on January 5th 2002. These models have two components, a CFD model built with the software FDS and a thermo-structural model built with the software Abaqus. Numerical models proved to be able to accurately predict the behavior of the bridge. These models were then used to perform a parametric study related to the discretization of the fire load, the use of fire curves included in the codes, and the influence of the live loads acting on the bridge. Results of the study show that: 
Please, cite this paper as:

Alos-Moya, J., Paya-Zaforteza, I., Garlock, M.E.M., Loma-Ossorio, E., Schiffner, D., Hospitaler, A. Analysis of a bridge failure due to fire using computational fluid dynamics and finite element models (2014) Engineering Structures, 68: 96-110.

DOI: 10.1016/j.engstruct.2014.02.022

(1) Real fires produce a strong variation of the temperatures along the bridge. Therefore, assuming a constant fire load along the bridge for medium-span or longspan bridges is unrealistic.

(2) Temperatures do not experience big changes in the region directly affected by flames, (areas with " $x$ " coordinate between 5 and $12 \mathrm{~m}$ in the case study analyzed in this paper), which suggests that assuming a uniform fire load in short span bridges is reasonable.

(3) Adiabatic temperatures obtained with the CFD model do not appreciably change within a given face of a girder cross section. Therefore, only one CFD model temperature sensor is necessary in each face of the girder where the temperatures are measured.

(4) When approximating adiabatic temperature curves with stepped curves, a step length of $2.33 \mathrm{~m}$ corresponding to $\mathrm{L} / 16$ ( $\mathrm{L}$ being the span length of the bridge) is recommended to obtain good results in bridges with span length around $37 \mathrm{~m}$. Note that span lengths or fire footprints different than those studied in this paper need additional study and might require a different step length.

(5) Fire induces longitudinal movements in the bridge which are higher than the width of the expansion joint. Therefore, numerical models must be capable to take into account the influence of an adjacent span or abutment.

(6) The direct use in medium-span or long-span bridges of curves included in the codes such as the standard or the hydrocarbon fire is not advisable. Additional research is required to see how these curves can be scaled to represent real fire scenarios.

(7) The amount of live load acting on the bridge has little effect on its fire response.

The numerical models proposed and validated in this paper are complex but can be used to perform a forensic engineering analysis of a bridge damaged by a fire and to study how bridge performance in fire events can be improved. Additionally, and if complementary experimental research and extensive parametric studies are carried out, these numerical models can be used to develop simpler design methodologies to assess the effects of fire on bridges. Future work in the area of bridge fires should include when possible the analysis of the entire bridge deck. By doing so, the numerical model could (a) capture the load 
Please, cite this paper as:

Alos-Moya, J., Paya-Zaforteza, I., Garlock, M.E.M., Loma-Ossorio, E., Schiffner, D., Hospitaler, A. Analysis of a bridge failure due to fire using computational fluid dynamics and finite element models (2014) Engineering Structures, 68: 96-110.

DOI: 10.1016/j.engstruct.2014.02.022

redistribution that happens when a bridge girder fails and (b) adequately reproduce the restraint imposed by the concrete slab to the displacements of the girders.

\section{Acknowledgements.}

Funding for this research has been provided by the Spanish Ministry of Science and Innovation (research project BIA 2011-27104) and the Universitat Politècnica de València (Research and Development Support Program PAID-06-11). Funding has also been provided to Dr. Maria Garlock by the National Science Foundation (NSF) under award number CMMI-1068252. The authors are grateful to R. King from the Federal Highway Administration of the USA, J. Black and T. Colquett from the Alabama Department of Transportation, J. Glassman from Princeton University, J.V. Aguado from Ecole Centrale de Nantes and to J. Hidalgo from the University of Edinburgh for all the information and support provided. All opinions expressed in this paper are the authors' and do not necessarily reflect the policies and views of the sponsors. 
Please, cite this paper as:

Alos-Moya, J., Paya-Zaforteza, I., Garlock, M.E.M., Loma-Ossorio, E., Schiffner, D., Hospitaler, A. Analysis of a bridge failure due to fire using computational fluid dynamics and finite element models (2014) Engineering Structures, 68: 96-110.

DOI: 10.1016/j.engstruct.2014.02.022

References

[1] Chang S and Nojima N. Measuring post-disaster transportation system performance: the 1995 Kobe earthquake in comparative perspective. Transportation Research Part A 2001; 35: 475-484.

[2] Zhu S., Levinson D, Liu HX, Harder K. The traffic and behavioral effects of the I-35W Mississippi River bridge collapse . Transportation Research Part A: Policy and Practice 201044 (10): 771-784.

[3] Ghosn M, Moses F, Wang J. NCHRP Report 489. Design of Highway Bridges for Extreme Events. Transportation Research Board of the National Academies. Washington D.C., USA. 2003.

[4] Cheng J. Reliability analysis of the Sutong Bridge Tower under ship impact loading, Structure and Infraestructure, doi: 10.1080/15732479.2012.757792

[5] San Francisco Gate. The Maze Meltdown. www.sfgate.com. Accessed August 17, 2011.

[6] Chung P., Wolfe R.W., Ostrom T., Hida S. Editors. Accelerated Bridge Construction Applications in California- A "Lessons Learned. Report issued by the California Department of Transportation, 55 pages. 2008.

[7] 6 abc action news. Driver killed in fiery truck crash on NJ Turnpike.

www.abclocal.go.com/wpvi/index. Accessed November 28, 2012.

[8] New York State Department of Transportation. Bridge Fire Incidents in New York State (Private Correspondence with Prof. M. Garlock), New York State Department of Transportation, USA, 2011.

[9] Garlock ME, Paya-Zaforteza I, Gu L, Kodur V. Fire Hazard in Bridges: Review, Assesment and Repair Strategies. Engineering Structures 2012;35:89-98.

[10] Buchanan AH. Structural Design for Fire Safety. John Wiley \& Sons, Chichester, United Kingdom, 2002.

[11] Couto C, Vila Real P, Lopes N, Rodrigues JP. Buckling analysis of braced and unbraced steel frames exposed to fire. Engineering Structures 2013; 49: 541-59.

[12] Quiel SE, Garlock MEM, Paya-Zaforteza I. Closed Form Procedure for Predicting the Capacity and Demand of Steel Beam-Columns under Fire. ASCE Journal of Structural Engineering 2011; 137: $967-76$

[13] Gunalan S, Mahen Mahendran M. Development of improved fire design rules for cold-formed steel wall systems. Journal of Constructional Steel Research 2013; 88:339-62. 
Please, cite this paper as:

Alos-Moya, J., Paya-Zaforteza, I., Garlock, M.E.M., Loma-Ossorio, E., Schiffner, D., Hospitaler, A. Analysis of a bridge failure due to fire using computational fluid dynamics and finite element models (2014) Engineering Structures, 68: 96-110.

DOI: 10.1016/j.engstruct.2014.02.022

[14] López-Colina C, Serrano-López MA, Gayarre FL, del Coz-Díaz JJ. Stiffness of the component 'lateral faces of RHS' at high temperature. Journal of Constructional Steel Research. 2011; 67(12): 1953-65.

[15] Moliner V, Espinos A, Romero ML, Hospitaler A. Fire behavior of eccentrically loaded slender high strength concrete-filled tubular columns. Journal of Constructional Steel Research 2013; 83:137146.

[16] Seif M, McAllister T. Stability of wide flange structural steel columns at elevated temperatures. Journal of Constructional Steel Research, 2013; 84:17-26

[17] Payá-Zaforteza I, Garlock M. A numerical investigation on the fire response of a steel girder bridge. Journal of Constructional Steel Research 2012; 75: 93-103.

[18] Chen W, Duan L. Bridge Engineering Handbook. New York, 2000

[19] Mc Grattan K, McDermott R, Hostikka S, Floyd J. Fire Dynamics Simulator (version 5). User's Guide. NIST Special Publication 1019-5, Gaithersburg, MD, USA, 2010.

[20] Simulia. Abaqus/standard version 6.9 user's manual; 2009.

[21] Aziz E, Kodur V. An approach for evaluating the residual strength of fire exposed bridge girders. Journal of Constructional Steel Research 2013; 88: 34-42.

[22] Powerpoint presentation emailed to Prof. Maria Garlock by Robert King of the Alabama Department of Transportation on July 8, 2010.

[23] Barkley T, Strasburg G. Bridge Rebuilt on the Fast Track. Public Roads 2002; 66(2).

[24] Mc Grattan K, McDermott R, Hostikka S, Floyd J. Fire Dynamics Simulator (Version 5). Technical Reference Guide. Volume 3: Validation. NIST Special Publication 1018-5, Gaithersburg, MD, USA, 2010.

[25] Alós-Moya J. Análisis del colapso frente al fuego del paso superior de la interestatal I-65 dirección Sur sobre la 1-65 dirección Norte en el ramal Sur del intercambiador con la interestatal I20/59 situado en Birmingham, Alabama, Estados Unidos. Analysis of the failure due to fire of the I-65 flyover in Birmingham, Alabama, United States. Master Thesis, In Spanish, Valencia, 2012.

[26] Wickström U, Dat Duthinh D, McGrattan K. Adiabatic Surface Temperature for Calculating Heat Transfer to Fire Exposed Structures. Interflam 2007. September 2007, Vol. 2: 943-953. 
Please, cite this paper as:

Alos-Moya, J., Paya-Zaforteza, I., Garlock, M.E.M., Loma-Ossorio, E., Schiffner, D., Hospitaler, A. Analysis of a bridge failure due to fire using computational fluid dynamics and finite element models (2014) Engineering Structures, 68: 96-110.

DOI: 10.1016/j.engstruct.2014.02.022

[27] Mc Grattan K, Hostikka S, Floyd J, Baum H,Rehm R, Mell W, McDermott. Fire Dynamics

Simulator (Version 5). Technical Reference Guide. Volume 1: Mathematical model. NIST Special Publication 1018-5, Gaithersburg, MD, USA, 2010.

[28] Tewarson, A. Generation of Heat and Chemical Compounds in Fires, In: Walton, W.D. editor. SFPE Handbook of Fire Protection Engineering, 4th edition, Quincy, MA. 2008, Section 3, Chapter 4, p. 3/82-161.

[29] Peris-Sayol G, Alós-Moya J, Payá-Zaforteza I, Hospitaler-Pérez A. A parametric study on the thermo-mechanical response of a multi-girder steel bridge submitted to real fires. Informes de la Construcción 2014, Accepted for publication.

[30] Karlsson, B, Quintiere, J. G. Enclosure Fire Dynamics. Washington, D.C.: CRC Press, 1999.

[31] Quintiere, J.G. Surface Flame Spread, In: Beyler, C.L. editor. SFPE Handbook of Fire Protection Engineering, 4th edition, Quincy, MA. 2008, Section 2, Chapter 12, p. 2/246-257.

[32] European Committee for Standardization (CEN). EN 1994-1-2:2005 Eurocode 4 Design of composite steel and concrete structures, Part 1-2: General rules - Structural fire design, European Committee for Standardization. Brussels, Belgium. 2005.

[33] European Committee for Standardization (CEN). EN 1991-1-2:2002 Eurocode 1: Actions on structures - Part 1-2: General Actions - Actions on structures exposed to fire. Brussels, Belgium. 2002.

[34] European Committee for Standardization (CEN). Eurocode 1 Actions on Structures, Part 2: Traffic loads on bridges, European Committee for Standardization. Brussels, Belgium. 2003. [35] American Association of State Highway and Transportation Officials (AASHTO). LRFD Bridge design specifications. Washington D.C, USA, 2009. 
Please, cite this paper as:

Alos-Moya, J., Paya-Zaforteza, I., Garlock, M.E.M., Loma-Ossorio, E., Schiffner, D., Hospitaler, A. Analysis of a bridge failure due to fire using computational fluid dynamics and finite element models (2014) Engineering Structures, 68: 96-110.

DOI: 10.1016/j.engstruct.2014.02.022

Table 1. Parameters and results of the analyses carried out for model validation.

\begin{tabular}{|c|c|c|c|c|c|c|c|}
\hline \multirow{2}{*}{$\begin{array}{c}\text { Parametric } \\
\text { Study }\end{array}$} & \multirow{2}{*}{$\begin{array}{l}\text { Analysis } \\
\text { name }\end{array}$} & \multirow{2}{*}{$\begin{array}{c}\text { HRRPUA }_{\text {MAX }} \\
\text { spill fire } \\
\left(\mathbf{k W} / \mathbf{m}^{2}\right)\end{array}$} & \multirow{2}{*}{$\begin{array}{l}\text { Number of } \\
\text { Temperature } \\
\text { Steps }\end{array}$} & \multirow{2}{*}{$\begin{array}{l}\text { Axial } \\
\text { restraint } \\
\text { at the } \\
\text { North } \\
\text { support }\end{array}$} & \multicolumn{3}{|c|}{ Failure } \\
\hline & & & & & $\begin{array}{l}\text { Time } \\
\text { (min) }\end{array}$ & Mode $^{a}$ & $\begin{array}{l}\text { Maximum } \\
\text { deflection } \\
\text { (m) }\end{array}$ \\
\hline \multirow{5}{*}{$\begin{array}{c}\text { Fire Load } \\
\text { (HRRPUA) }\end{array}$} & 2500-16-fix & 2500 & 16 & Fixed & 1.6 & $\begin{array}{c}\mathrm{LB}, \mathrm{R}, \mathrm{S}, \\
\mathrm{WB}\end{array}$ & 0.54 \\
\hline & 2000-16-fix & 2000 & 16 & Fixed & 2 & $\mathrm{LB}, \mathrm{R}, \mathrm{WB}$ & 0.57 \\
\hline & 1500-16-fix & 1500 & 16 & Fixed & 3.8 & $\mathrm{LB}, \mathrm{R}, \mathrm{WB}$ & 0.86 \\
\hline & 1000-16-fix & 1000 & 16 & Fixed & 13.1 & LB, S, WB & 1.91 \\
\hline & 500-16-fix & 500 & 16 & Fixed & $>30$ & $\mathrm{LB}, \mathrm{S}$ & 0.67 \\
\hline \multirow{4}{*}{$\begin{array}{l}\text { Discretization } \\
\text { of the } \\
\text { temperature }\end{array}$} & 1000-8-fix & 1000 & 8 & Fixed & 14.4 & $\begin{array}{l}\mathrm{LB}, \mathrm{R}, \mathrm{S}, \\
\mathrm{WB}\end{array}$ & 1.87 \\
\hline & 1000-4-fix & 1000 & 4 & Fixed & 14.8 & $\begin{array}{l}\mathrm{LB}, \mathrm{R}, \mathrm{S}, \\
\quad \mathrm{WB}\end{array}$ & 1.26 \\
\hline & 1000-2-fix & 1000 & 2 & Fixed & 11.4 & LB, S, WB & 0.76 \\
\hline & 1000-1-fix & 1000 & 1 & Fixed & 16.8 & $\mathrm{LB}, \mathrm{S}$ & 0.83 \\
\hline $\begin{array}{l}\text { Boundary } \\
\text { condition }\end{array}$ & $1000-16$-fre & 1000 & 16 & Free & 12.3 & $\mathrm{LB}, \mathrm{S}$ & 1.36 \\
\hline
\end{tabular}

${ }^{a}$ LB: Instability due to lateral buckling, R: Instability noticed by the movement of north support (roller) towards the center of span, S: Ultimate strain reached, WB: Instability due to web buckling on north side 
Please, cite this paper as:

Alos-Moya, J., Paya-Zaforteza, I., Garlock, M.E.M., Loma-Ossorio, E., Schiffner, D., Hospitaler, A. Analysis of a bridge failure due to fire using computational fluid dynamics and finite element models (2014) Engineering Structures, 68: 96-110.

DOI: 10.1016/j.engstruct.2014.02.022

Table 2. Fire scenario study description and results.

\begin{tabular}{|c|c|c|c|c|}
\hline \multirow{2}{*}{$\begin{array}{l}\text { Fire Scenario } \\
\text { Name }\end{array}$} & \multirow{2}{*}{ Description } & \multicolumn{3}{|c|}{ Failure } \\
\hline & & $\begin{array}{l}\text { Time } \\
\text { (min) }\end{array}$ & Mode $^{a}$ & $\begin{array}{c}\text { Maximum } \\
\text { deflection (m) }\end{array}$ \\
\hline CFD & $\begin{array}{l}\text { Validated model of case } \\
\text { study (1000-16-fix) }\end{array}$ & 13.1 & LB, R, S, WB & 1.91 \\
\hline Standard & Eurocode (EC-1 Part 1-2) & 17.4 & LB, WB, S & 1.19 \\
\hline Hydrocarbon & Eurocode (EC-1 Part 1-2) & 4.3 & LB, WB, S & 1.14 \\
\hline
\end{tabular}

${ }^{a}$ LB: Instability due to lateral buckling, R: Instability noticed by the movement of north (roller) end towards the center of span, S: Ultimate strain reached, WB: Instability due to web buckling 
Please, cite this paper as:

Alos-Moya, J., Paya-Zaforteza, I., Garlock, M.E.M., Loma-Ossorio, E., Schiffner, D., Hospitaler, A. Analysis of a bridge failure due to fire using computational fluid dynamics and finite element models (2014) Engineering Structures, 68: 96-110.

DOI: 10.1016/j.engstruct.2014.02.022

Table 3. Live load study description and results.

\begin{tabular}{cccc}
\multirow{2}{*}{$\begin{array}{c}\text { Live Load } \\
\text { Combination }\end{array}$} & \multicolumn{3}{c}{ Failure } \\
\cline { 2 - 4 } & $\begin{array}{c}\text { Time } \\
(\mathbf{m i n})\end{array}$ & Mode $^{\mathrm{b}}$ & $\begin{array}{c}\text { Maximum } \\
\text { deflection }(\mathbf{m})\end{array}$ \\
\hline $\mathrm{G}^{\mathrm{c}}$ & 13.1 & LB, WB, S & 1.91 \\
$\mathrm{G}+0.3 \mathrm{Q}$ & 12.6 & LB, WB, S & 1.92 \\
$\mathrm{G}+0.5 \mathrm{Q}$ & 12 & LB, WB, S & 1.82 \\
$\mathrm{G}+\mathrm{Q}$ & 11.3 & LB, WB, S & 1.76 \\
\hline
\end{tabular}

${ }^{\mathrm{a}}$ G: dead load; Q: live load

${ }^{\mathrm{b}} \mathrm{B}$ : Instability due to lateral buckling, R: Instability noticed by the movement of north (roller) end towards the center of span, S: Ultimate strain reached, WB: Instability due to web buckling on north side

${ }^{\mathrm{c}}$ This baseline case with no live load is equal to analysis 1000-16-fix of Table 1 
Please, cite this paper as:

Alos-Moya, J., Paya-Zaforteza, I., Garlock, M.E.M., Loma-Ossorio, E., Schiffner, D., Hospitaler, A. Analysis of a bridge failure due to fire using computational fluid dynamics and finite element models (2014) Engineering Structures, 68: 96-110.

DOI: 10.1016/j.engstruct.2014.02.022

(a)

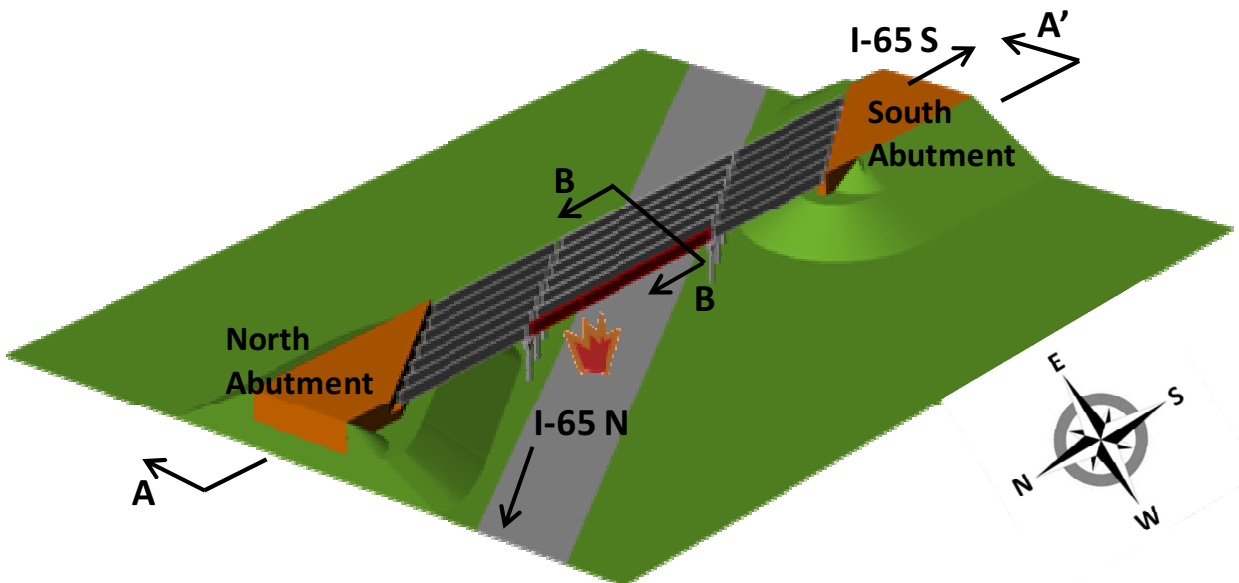

(b)

Section A-A

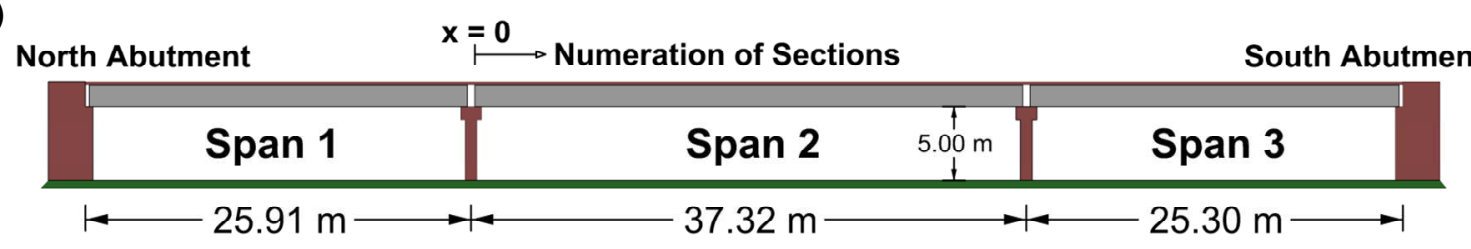

(c)

\section{Section B-B'}

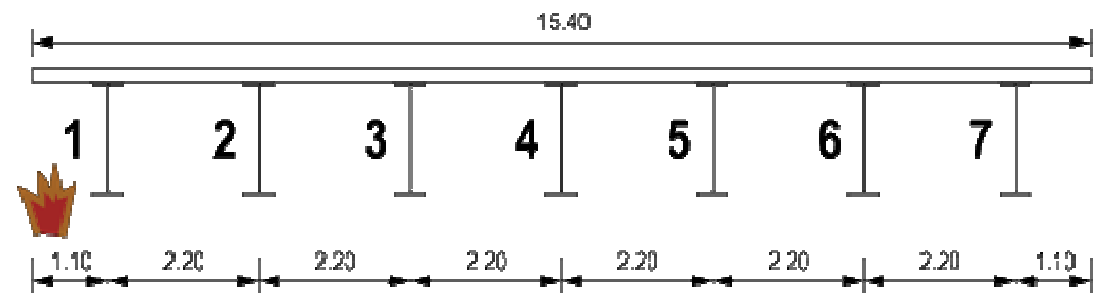

Figure 1. I-65 overpass: (a) general view, (b) elevation, (c) cross section 
Please, cite this paper as:

Alos-Moya, J., Paya-Zaforteza, I., Garlock, M.E.M., Loma-Ossorio, E., Schiffner, D., Hospitaler, A. Analysis of a bridge failure due to fire using computational fluid dynamics and finite element models (2014) Engineering Structures, 68: 96-110.

DOI: 10.1016/j.engstruct.2014.02.022
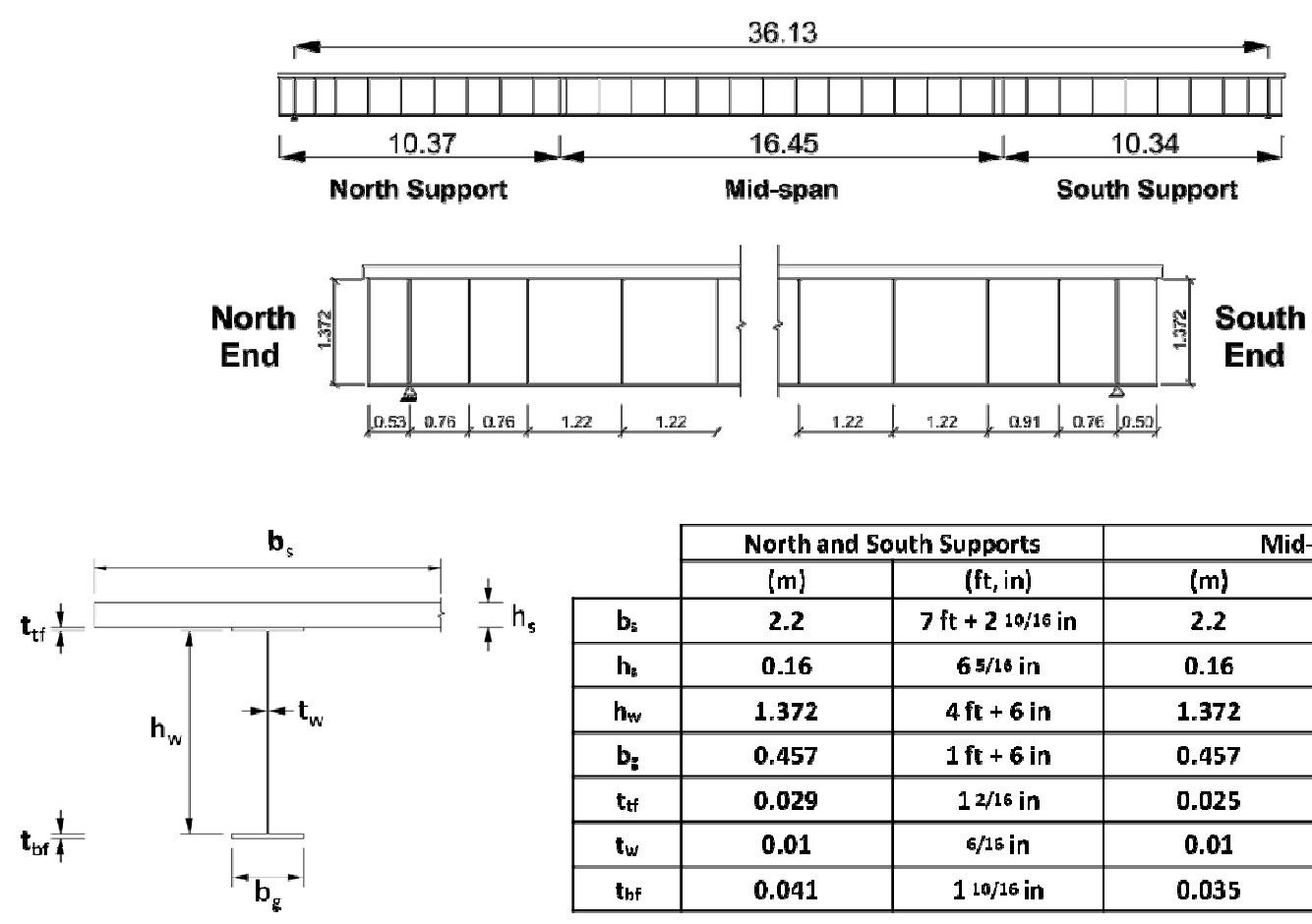

\begin{tabular}{|c|c|c|c|c|}
\hline & \multicolumn{2}{|c|}{ North and South Supports } & \multicolumn{2}{|c|}{ Mid-Span } \\
\hline & {$[\mathrm{m})$} & (ft, in) & $(\mathrm{m})$ & $(\mathrm{ft}, \mathrm{in})$ \\
\hline$b_{2}$ & 2.2 & $7 \mathrm{ft}+210 / 16$ in & 2.2 & $7 \mathrm{ft}+210 / 16$ in \\
\hline $\mathbf{h}_{\mathbf{i}}$ & 0.16 & $65 / 16$ in & 0.16 & $65 / 16$ in \\
\hline $\mathbf{h}_{w}$ & 1.372 & $4 \mathrm{ft}+6$ in & 1.372 & $4 \mathrm{ft}+6$ in \\
\hline$b_{7}$ & 0.457 & $1 \mathrm{ft}+6$ in & 0.457 & $1 \mathrm{ft}+6$ in \\
\hline$t_{t f}$ & 0.029 & $12 / 16$ in & 0.025 & 1 in \\
\hline$t_{w}$ & 0.01 & $6 / 15$ in & 0.01 & $5 / 16$ in \\
\hline$t_{\text {thf }}$ & 0.041 & $110 / 16$ in & 0.035 & $16 / 16$ in \\
\hline
\end{tabular}

Figure 2. I-65 overpass. Elevation and geometric definition of Girder 1. Except on supports, stiffeners were located only in the side of Girder 1 facing Girder 2. 
Please, cite this paper as:

Alos-Moya, J., Paya-Zaforteza, I., Garlock, M.E.M., Loma-Ossorio, E., Schiffner, D., Hospitaler, A. Analysis of a bridge failure due to fire using computational fluid dynamics and finite element models (2014) Engineering Structures, 68: 96-110.

DOI: 10.1016/j.engstruct.2014.02.022

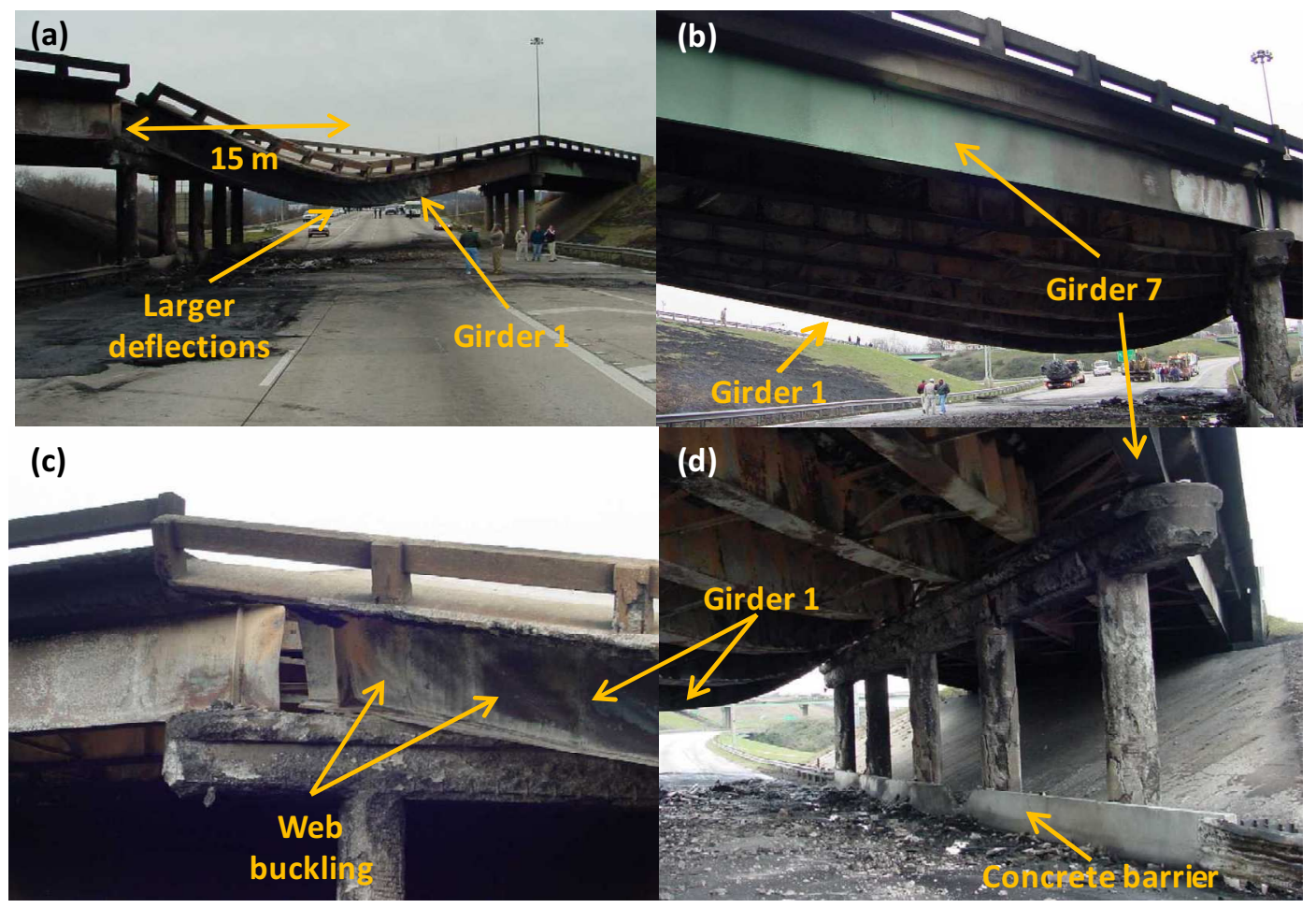

Figure 3. Damage caused by the fire to the steel girders of the I-65 overpass. Source of the images: Alabama Department of Transportation. 
Please, cite this paper as:

Alos-Moya, J., Paya-Zaforteza, I., Garlock, M.E.M., Loma-Ossorio, E., Schiffner, D., Hospitaler, A. Analysis of a bridge failure due to fire using computational fluid dynamics and finite element models (2014) Engineering Structures, 68: 96-110.

DOI: 10.1016/j.engstruct.2014.02.022

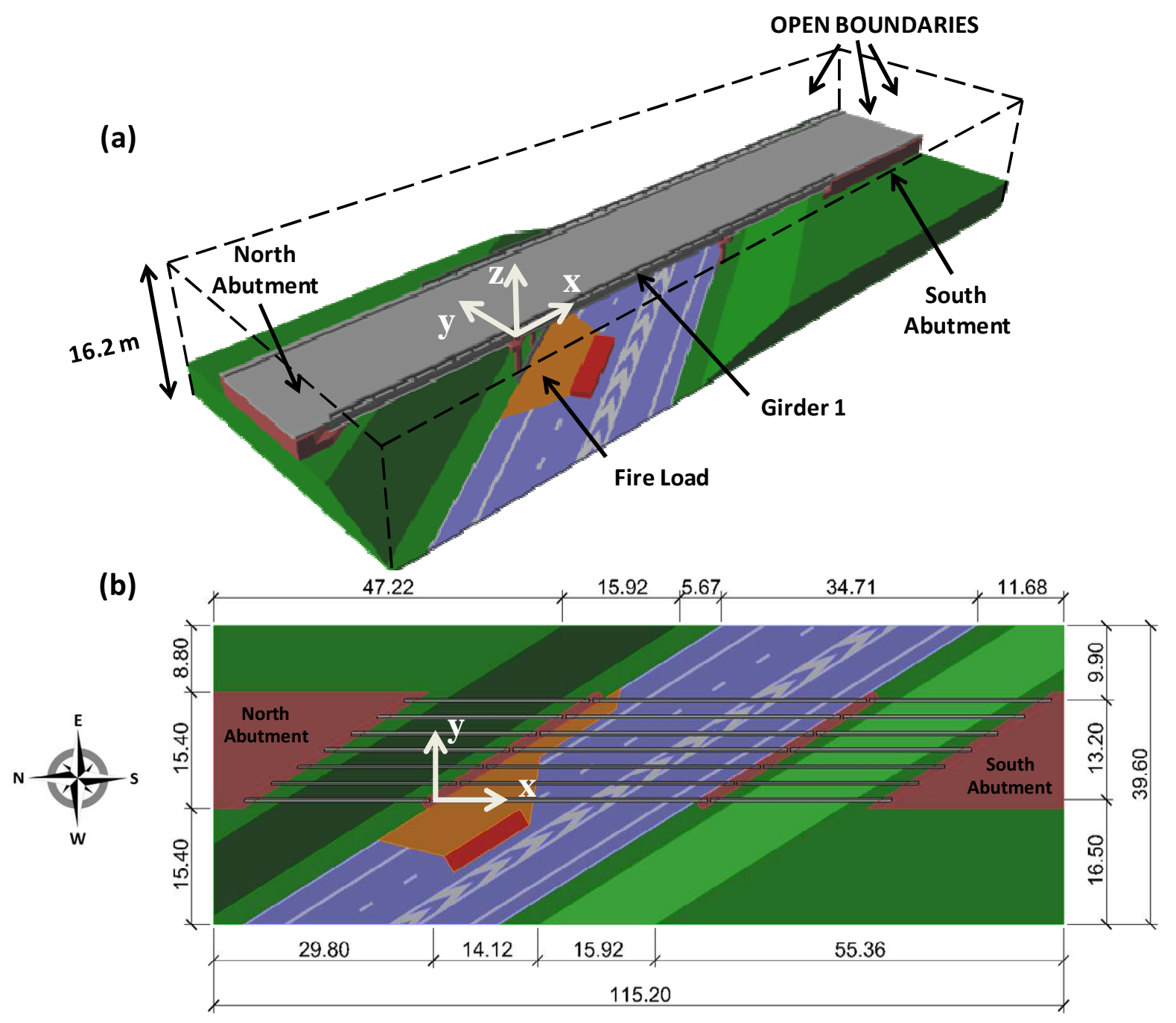

Figure 4. FDS model: general view (top) and plan view (bottom) of the control volume. 
Please, cite this paper as:

Alos-Moya, J., Paya-Zaforteza, I., Garlock, M.E.M., Loma-Ossorio, E., Schiffner, D., Hospitaler, A. Analysis of a bridge failure due to fire using computational fluid dynamics and finite element models (2014) Engineering Structures, 68: 96-110.

DOI: 10.1016/j.engstruct.2014.02.022

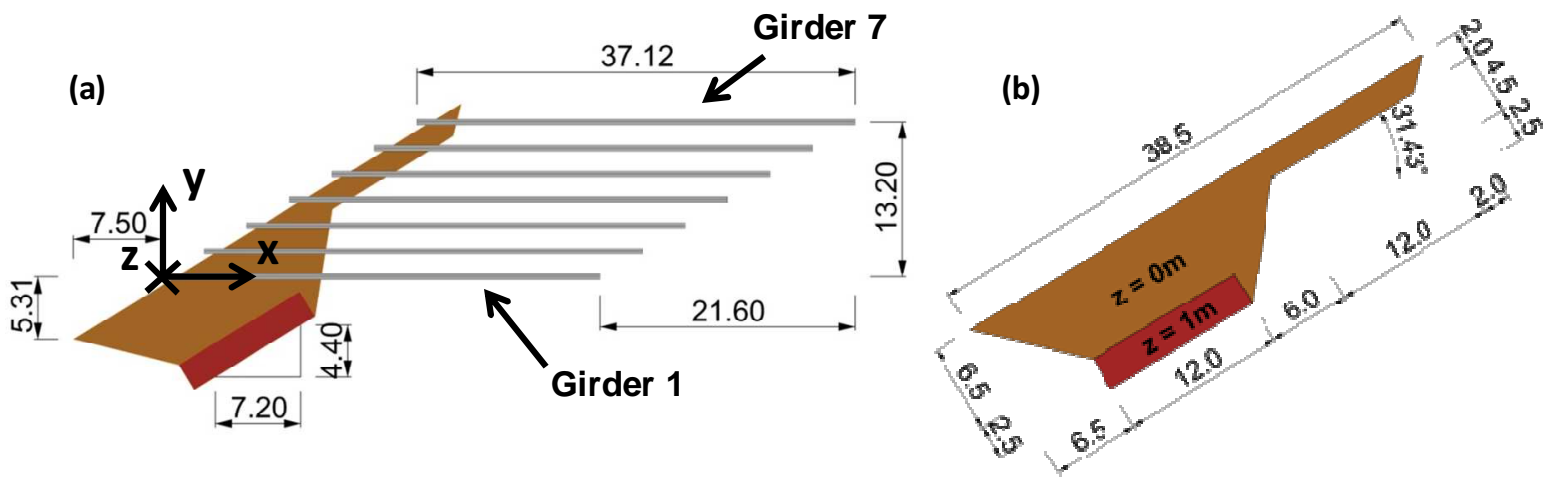

Figure 5. FDS model fire load location (a) and geometric definition (b) of the fire load. 
Please, cite this paper as:

Alos-Moya, J., Paya-Zaforteza, I., Garlock, M.E.M., Loma-Ossorio, E., Schiffner, D., Hospitaler, A. Analysis of a bridge failure due to fire using computational fluid dynamics and finite element models (2014) Engineering Structures, 68: 96-110.

DOI: 10.1016/j.engstruct.2014.02.022

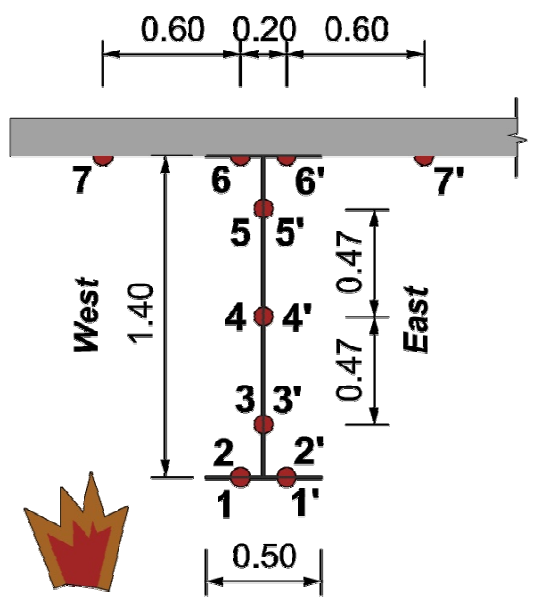

Figure 6. FDS model. Adiabatic surface temperature sensors in a typical monitored cross section. 
Please, cite this paper as:

Alos-Moya, J., Paya-Zaforteza, I., Garlock, M.E.M., Loma-Ossorio, E., Schiffner, D., Hospitaler, A. Analysis of a bridge failure due to fire using computational fluid dynamics and finite element models (2014) Engineering Structures, 68: 96-110.

DOI: 10.1016/j.engstruct.2014.02.022

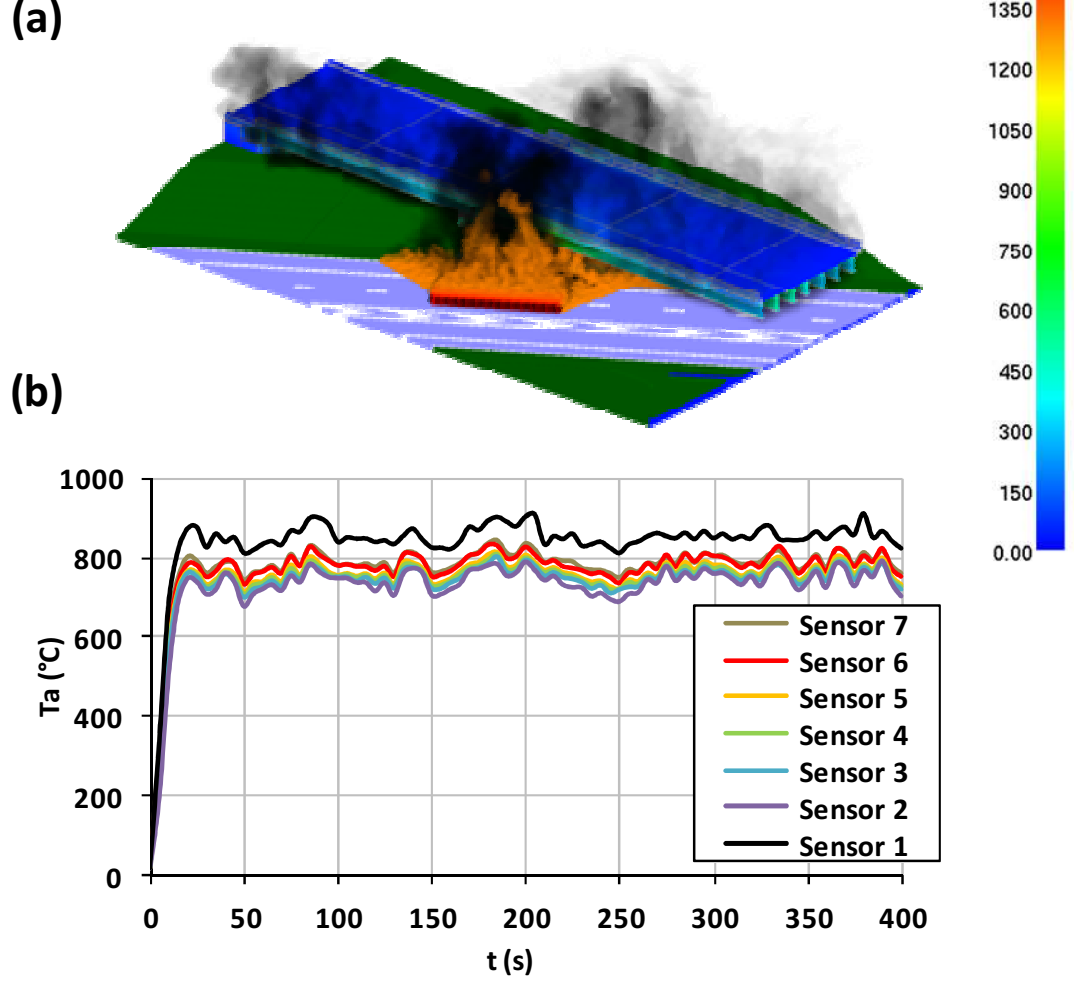

Figure 7. FDS results: (a) general view of the $1-65$ overpass 3 minutes after the beginning of the fire event, (b) evolution of the adiabatic temperatures $\left(T_{a}\right)$ in the cross section of Girder 1 located at $7.5 \mathrm{~m}$ of its north end. Assumed HRRPUA $A_{M A X, S P I L L}=1000 \mathrm{~kW} / \mathrm{m}^{2}$. Only half of the bridge is shown. 
Please, cite this paper as:

Alos-Moya, J., Paya-Zaforteza, I., Garlock, M.E.M., Loma-Ossorio, E., Schiffner, D., Hospitaler, A. Analysis of a bridge failure due to fire using computational fluid dynamics and finite element models (2014) Engineering Structures, 68: 96-110.

DOI: 10.1016/j.engstruct.2014.02.022

(a)

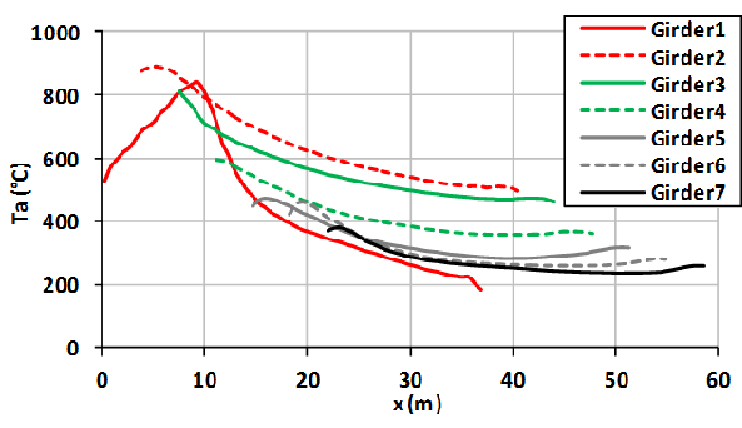

(b)

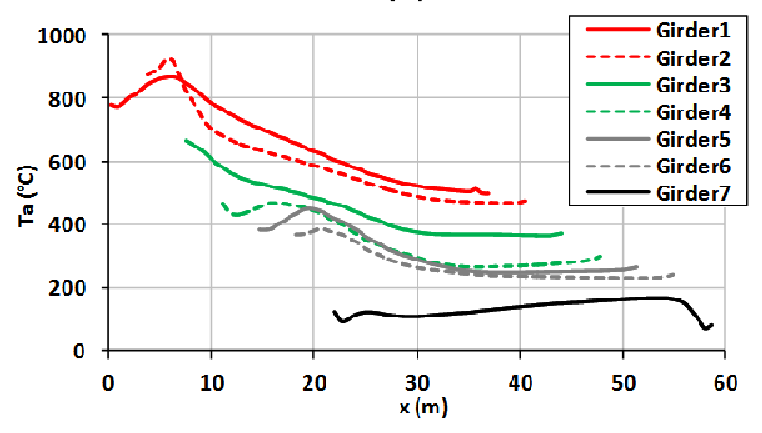

(c)

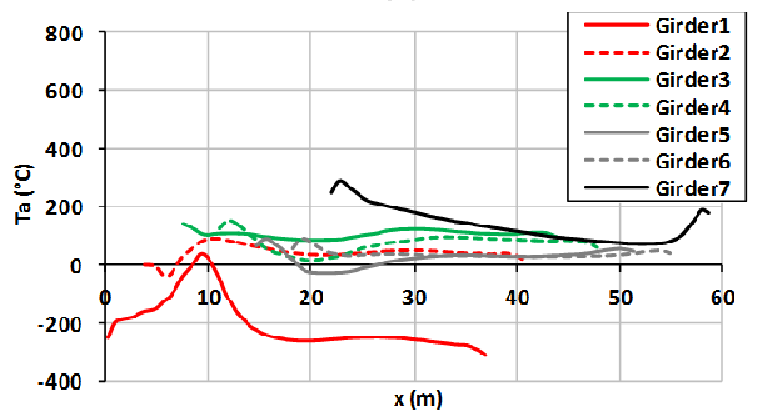

Figure 8. Average values of the adiabatic temperatures $\left(T_{a}\right)$ along the mid-depth of the girders web: (a) West Face (Sensor 4 in Fig. 6), (b) East Face (Sensor 4' in Fig. 6), (c) difference between the values measured by sensors 4 and 4 '. Assumed HRRPUA $A_{\text {MAX,SPILL }}=1000 \mathrm{~kW} / \mathrm{m}^{2}$. 
Please, cite this paper as:

Alos-Moya, J., Paya-Zaforteza, I., Garlock, M.E.M., Loma-Ossorio, E., Schiffner, D., Hospitaler, A. Analysis of a bridge failure due to fire using computational fluid dynamics and finite element models (2014) Engineering Structures, 68: 96-110.

DOI: 10.1016/j.engstruct.2014.02.022

(a)

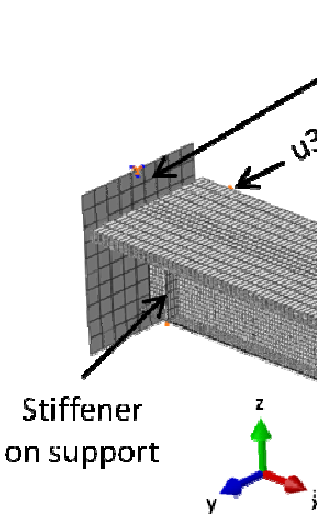

Rigid Body

(b)

(c)

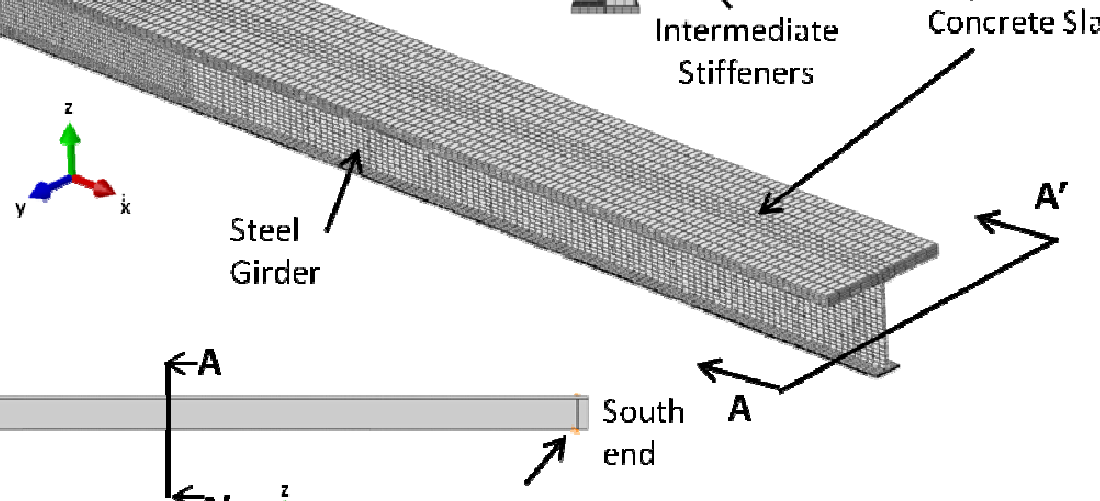

Roller

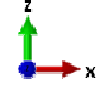

Pin support

Figure 9. Finite Element Modelof Girder 1 built with Abaqus: (a) 3D view of half girder, (b) Section A$A^{\prime}$, (c) elevation. 
Please, cite this paper as:

Alos-Moya, J., Paya-Zaforteza, I., Garlock, M.E.M., Loma-Ossorio, E., Schiffner, D., Hospitaler, A. Analysis of a bridge failure due to fire using computational fluid dynamics and finite element models (2014) Engineering Structures, 68: 96-110.

DOI: 10.1016/j.engstruct.2014.02.022

(a)
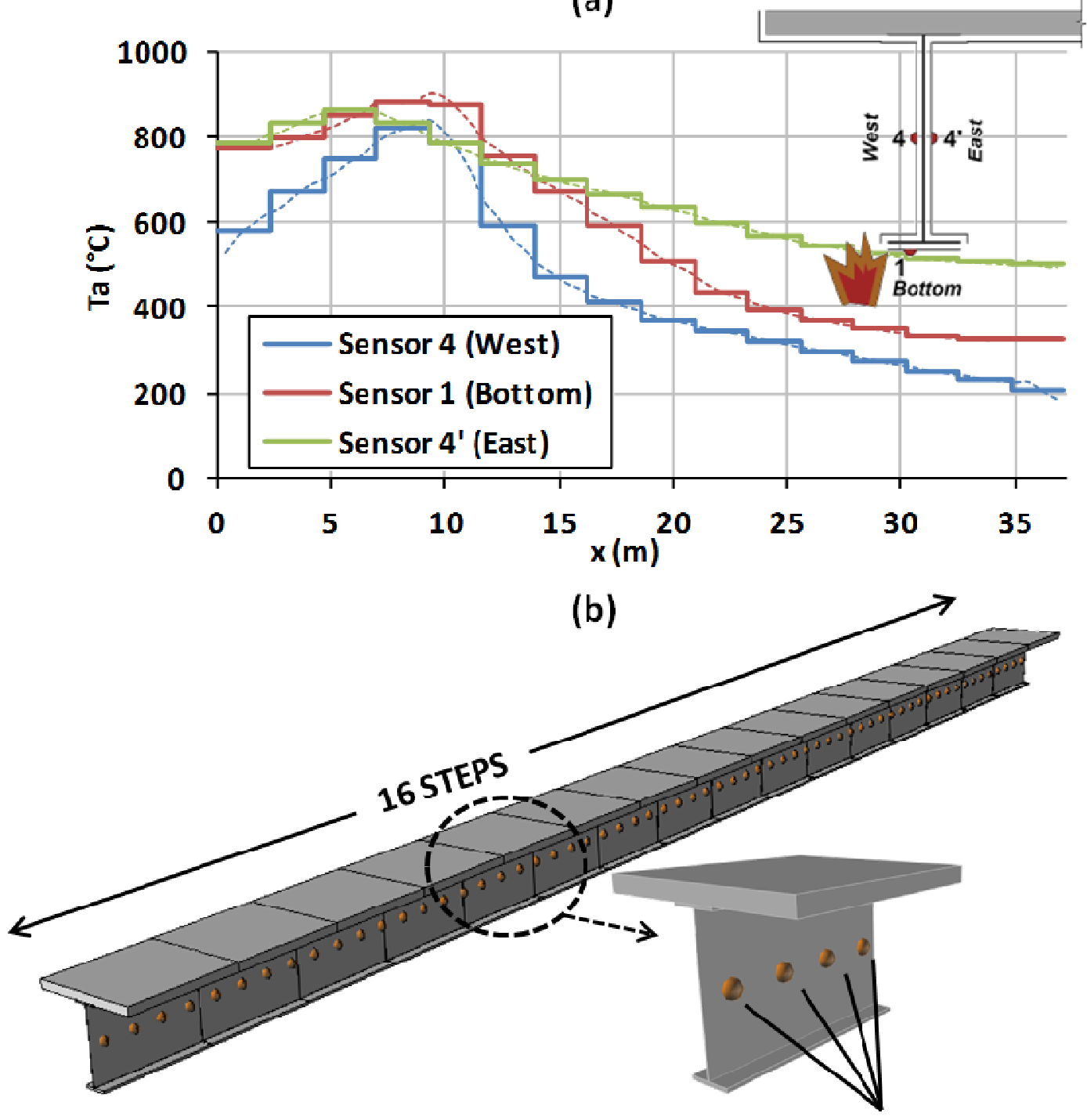

Ta, $\operatorname{STEP}=(\mathrm{Ta}, 1+\mathrm{Ta}, 2+\mathrm{Ta}, 3+\mathrm{Ta}, 4) / 4$

Figure 10. Girder 1. Example of a 16 step discretization of the adiabatic temperature curves for merging CFD with Abaqus. Assumed HRRPUA $A_{M A X, S P I L L}=1000 \mathrm{~kW} / \mathrm{m}^{2}$. (a) Adiabatic temperatures along the girder span. Dashed lines represent the smooth continuous CFD results. Solid lines represent the discretization. (b) Model showing the 16 steps and the calculation of the average temperature at each step. 
Please, cite this paper as:

Alos-Moya, J., Paya-Zaforteza, I., Garlock, M.E.M., Loma-Ossorio, E., Schiffner, D., Hospitaler, A. Analysis of a bridge failure due to fire using computational fluid dynamics and finite element models (2014) Engineering Structures, 68: 96-110.

DOI: 10.1016/j.engstruct.2014.02.022

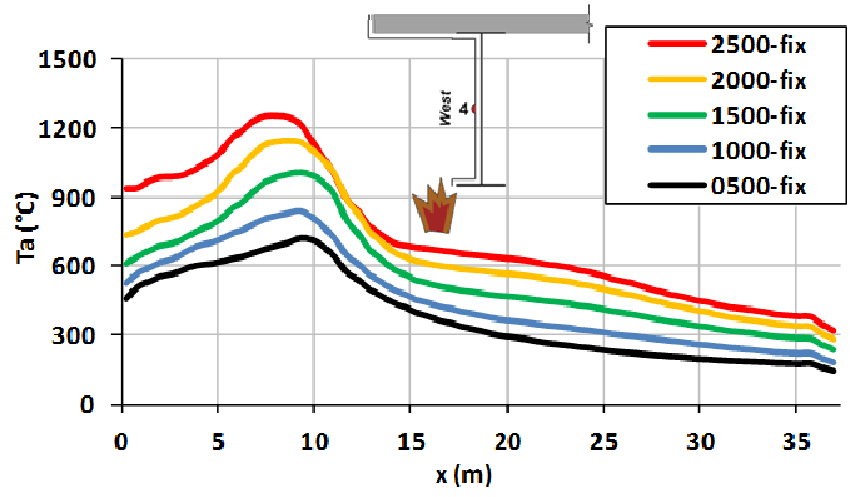

Figure 11. Effect of HRRPUA $A_{\text {MAX,SPILL }}$ on the steady state adiabatic temperatures for Girder 1 West face (sensor 4). 
Please, cite this paper as:

Alos-Moya, J., Paya-Zaforteza, I., Garlock, M.E.M., Loma-Ossorio, E., Schiffner, D., Hospitaler, A. Analysis of a bridge failure due to fire using computational fluid dynamics and finite element models (2014) Engineering Structures, 68: 96-110.

DOI: 10.1016/j.engstruct.2014.02.022

(a)

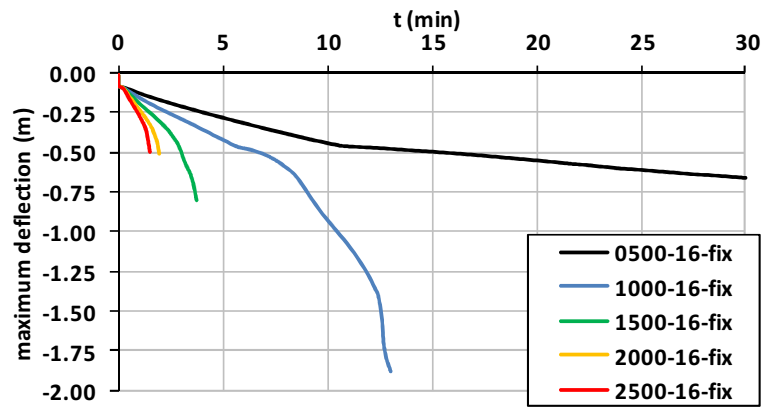

(b)

$x(m)$

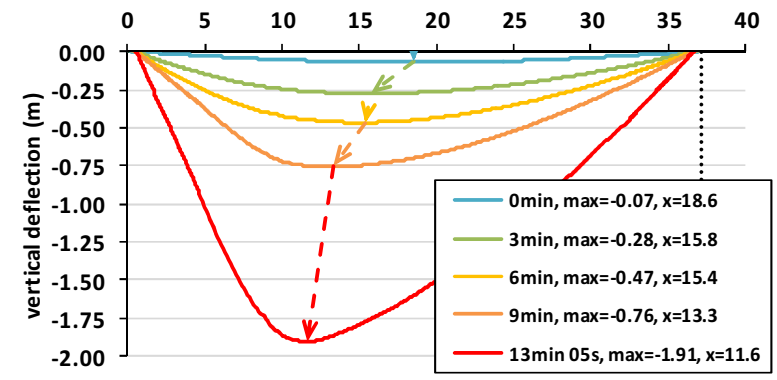

Figure 12. Effect of HRRPUA $A_{M A X}$, SPILL on the vertical displacement of the girder: (a) maximum displacement over time, and (b) displacement along the length of the girder for some discrete points in time for analysis 1000-16-fix. 
Please, cite this paper as:

Alos-Moya, J., Paya-Zaforteza, I., Garlock, M.E.M., Loma-Ossorio, E., Schiffner, D., Hospitaler, A. Analysis of a bridge failure due to fire using computational fluid dynamics and finite element models (2014) Engineering Structures, 68: 96-110.

DOI: 10.1016/j.engstruct.2014.02.022

(a)

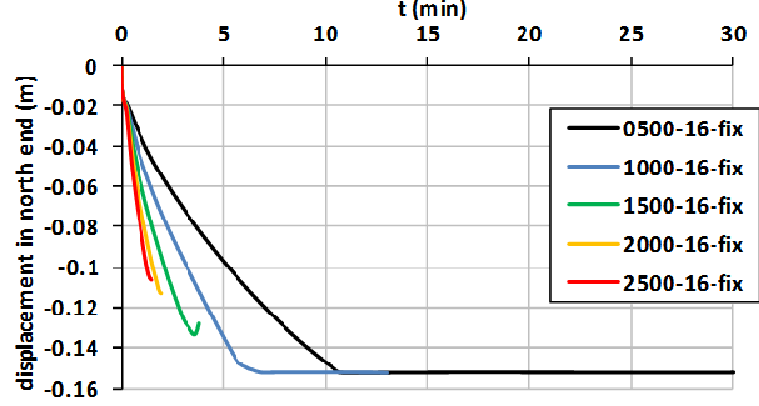

(b)

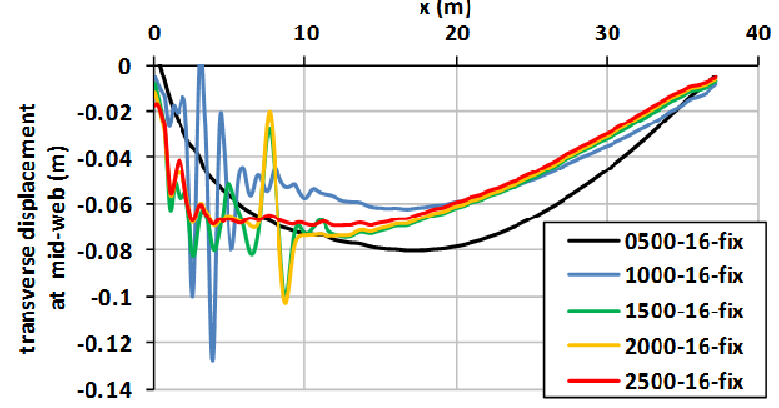

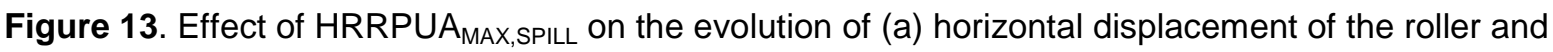
(b) transverse (out-of-plane) displacements at mid-web. 
Please, cite this paper as:

Alos-Moya, J., Paya-Zaforteza, I., Garlock, M.E.M., Loma-Ossorio, E., Schiffner, D., Hospitaler, A. Analysis of a bridge failure due to fire using computational fluid dynamics and finite element models (2014) Engineering Structures, 68: 96-110.

DOI: 10.1016/j.engstruct.2014.02.022

(a)

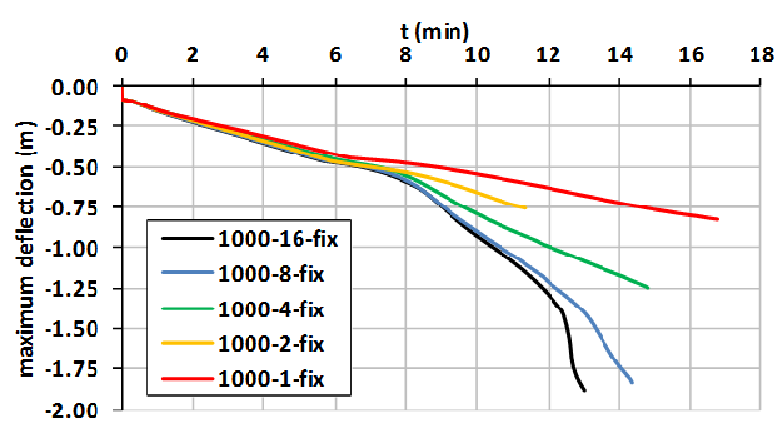

(b)

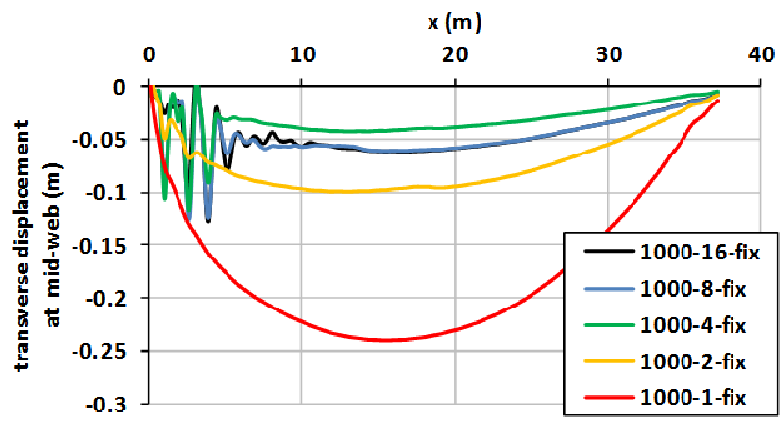

Figure 14. Effect of temperature discretization on the evolution of (a) maximum vertical displacement; and (b) transverse (out-of-plane) displacements of the mid-web. 
Please, cite this paper as:

Alos-Moya, J., Paya-Zaforteza, I., Garlock, M.E.M., Loma-Ossorio, E., Schiffner, D., Hospitaler, A. Analysis of a bridge failure due to fire using computational fluid dynamics and finite element models (2014) Engineering Structures, 68: 96-110.

DOI: 10.1016/j.engstruct.2014.02.022

(a)

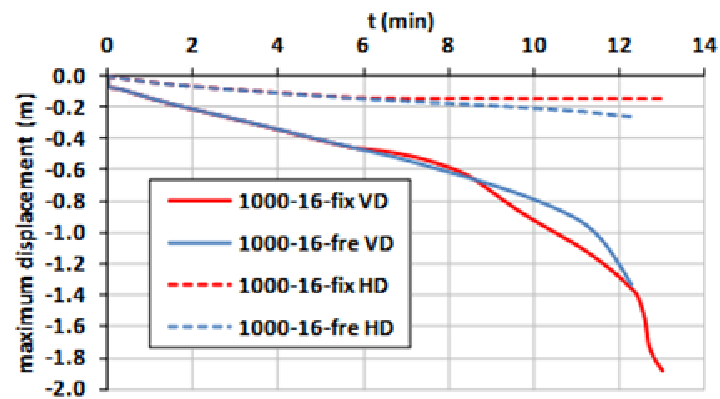

(b)

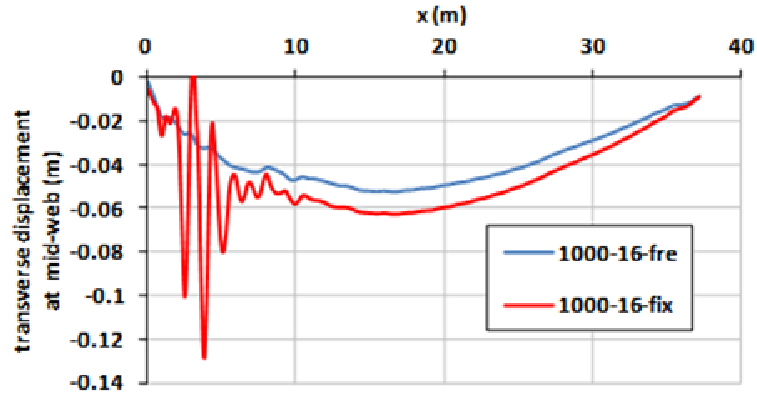

Figure 15. Effects of boundary conditions through a comparison of analyses 1000-16-fix and 100016-fre: (a) maximum vertical displacement (VD) and horizontal displacement (HD) of the roller and (b) transverse (out-of-plane) displacements of the web. 
Please, cite this paper as:

Alos-Moya, J., Paya-Zaforteza, I., Garlock, M.E.M., Loma-Ossorio, E., Schiffner, D., Hospitaler, A. Analysis of a bridge failure due to fire using computational fluid dynamics and finite element models (2014) Engineering Structures, 68: 96-110.

DOI: $10.1016 /$ j.engstruct.2014.02.022

(a)
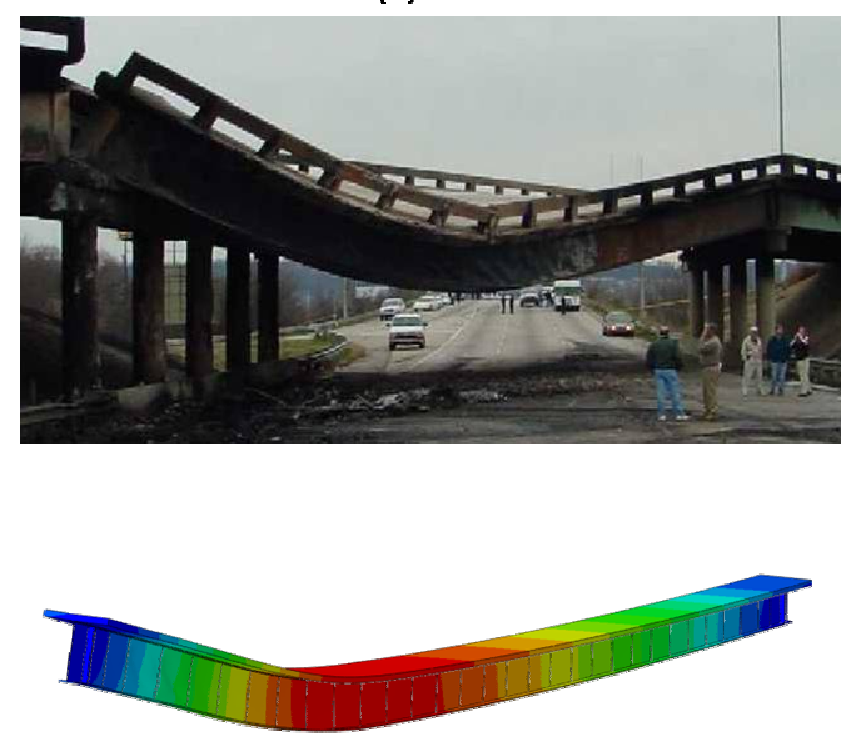

(b)
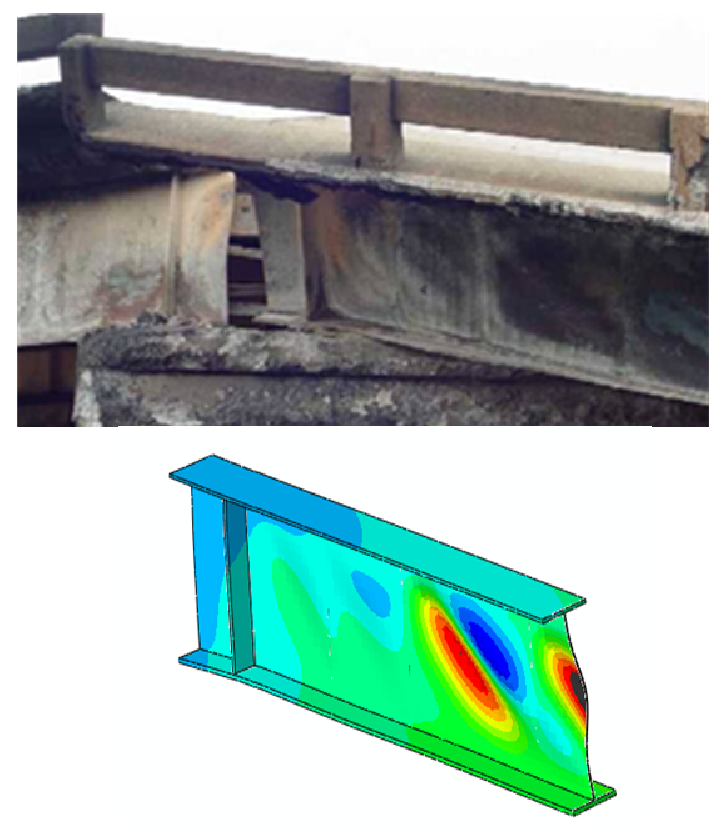

Figure 16. Comparison of validated model 1000-16-fix with images of the case study fire event: (a) Deformed shape of Girder 1 (West face). Red colors represent maximum values of vertical displacements; (b) close up of west face of Girder 1 at north support where web buckling is observed. Red colors represent maximum values of out of plane displacements. 
Please, cite this paper as:

Alos-Moya, J., Paya-Zaforteza, I., Garlock, M.E.M., Loma-Ossorio, E., Schiffner, D., Hospitaler, A. Analysis of a bridge failure due to fire using computational fluid dynamics and finite element models (2014) Engineering Structures, 68: 96-110.

DOI: 10.1016/j.engstruct.2014.02.022

(a)

\section{E}

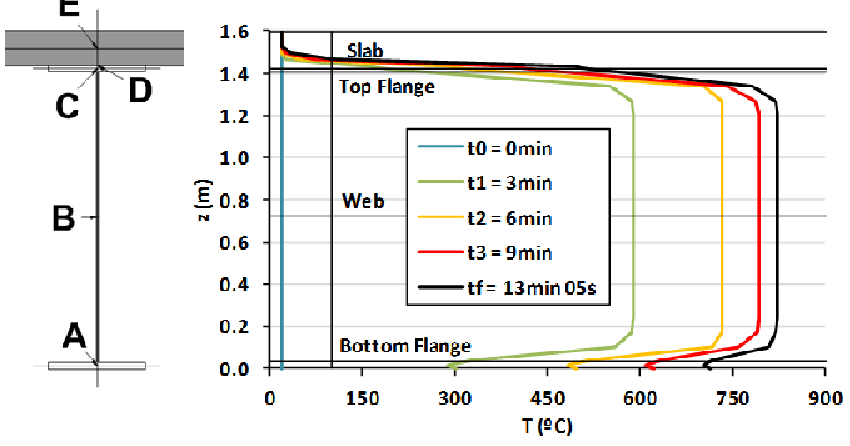

(b)

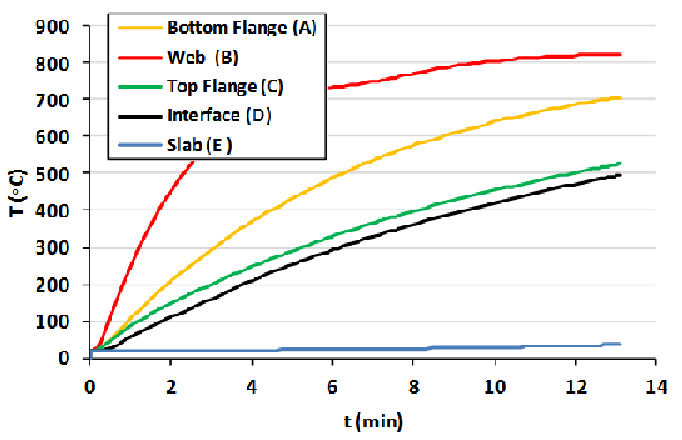

Figure 17. Section of Girder 1 located $7.5 \mathrm{~m}$ from the north end, analysis 1000-16-fix: (a) temperature distribution in the cross section at discrete points in time and, (b) temperature evolution at five points of the cross section of the bridge. All the points are in the vertical axis of the girder. 
Please, cite this paper as:

Alos-Moya, J., Paya-Zaforteza, I., Garlock, M.E.M., Loma-Ossorio, E., Schiffner, D., Hospitaler, A. Analysis of a bridge failure due to fire using computational fluid dynamics and finite element models (2014) Engineering Structures, 68: 96-110.

DOI: 10.1016/j.engstruct.2014.02.022

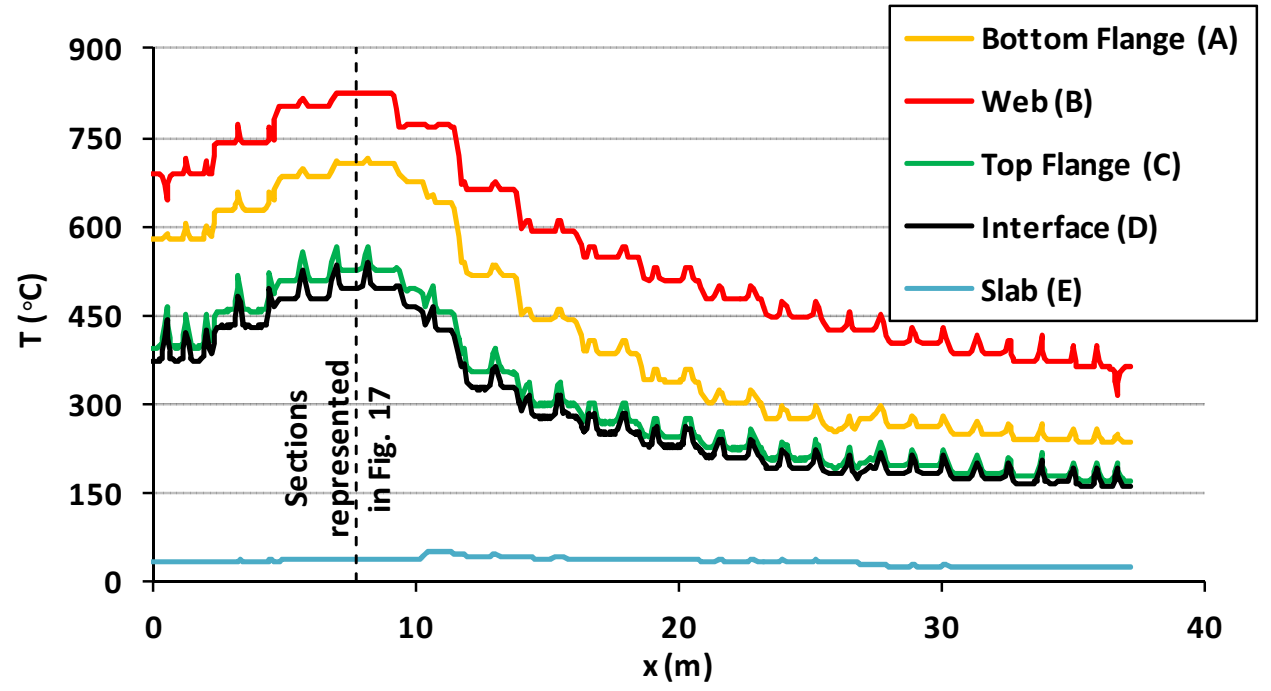

Figure 18. Girder 1 temperatures at the time of failure along the length at representative points of its cross section. 
Please, cite this paper as:

Alos-Moya, J., Paya-Zaforteza, I., Garlock, M.E.M., Loma-Ossorio, E., Schiffner, D., Hospitaler, A. Analysis of a bridge failure due to fire using computational fluid dynamics and finite element models (2014) Engineering Structures, 68: 96-110.

DOI: 10.1016/j.engstruct.2014.02.022

(a)

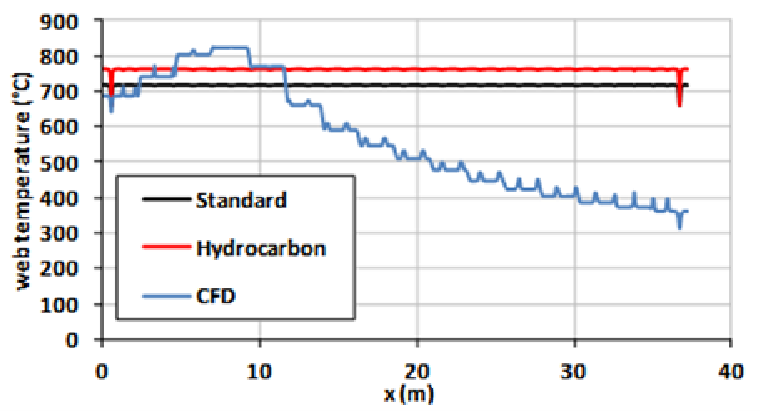

(b)

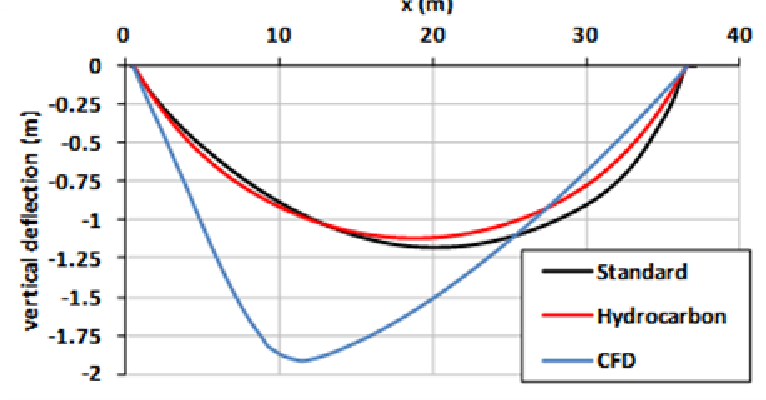

Figure 19. Influence of the fire scenario used to heat Girder 1: (a) temperatures in the web at the time of failure, (b) vertical deflections at the time of failure. 
Please, cite this paper as:

Alos-Moya, J., Paya-Zaforteza, I., Garlock, M.E.M., Loma-Ossorio, E., Schiffner, D., Hospitaler, A. Analysis of a bridge failure due to fire using computational fluid dynamics and finite element models (2014) Engineering Structures, 68: 96-110.

DOI: 10.1016/j.engstruct.2014.02.022

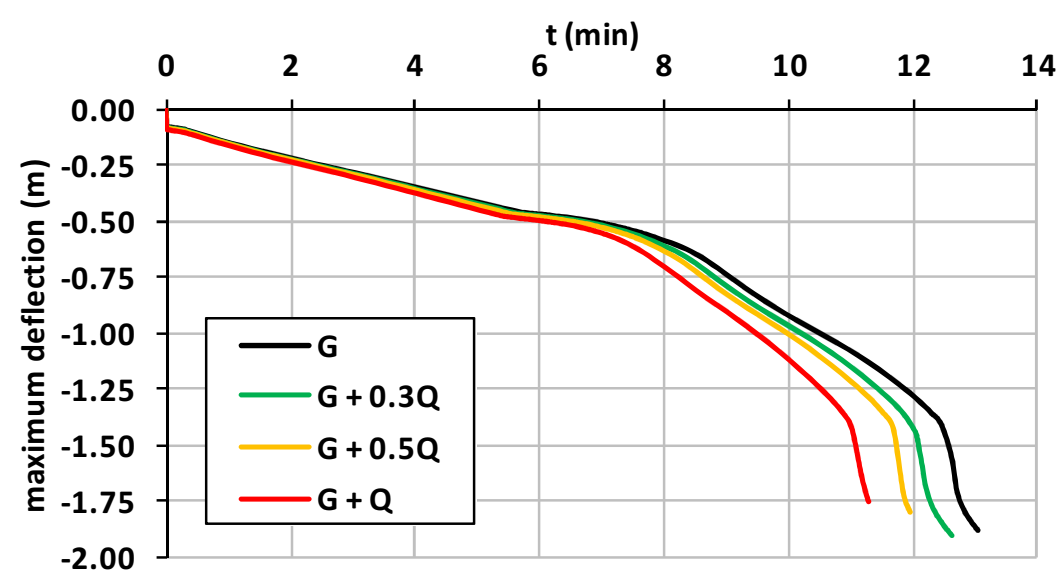

Figure 20. Influence of live load on the maximum deflection of Girder 1 over time. 